\title{
A New Paradigm for International Legal Studies: Prospects and Proposals*
}

\section{Richard Falk $\dagger$}

I believe that we are undergoing a major reorganization of international life at the present time which will result in drastic modification of the world order system that has prevailed since the Peace of Westphalia in 1648. This reorganization is being brought about through the efforts of powerful economic, political, and cultural actors on the world stage to cope with the challenge of growing interdependence during a period in which critical resources may be in short supply. Coping can be conceived in relation to immediate issues, such as shortfalls in fuel during the months ahead, or more structurally, as recurrent failure to satisfy basic human and societal needs. This reorganization of international life has two principal features-increased central guidance, and increased roles for nonterritorial actors. There are many uncertainties concerning the nature and orientation of the nonterritorial actors, the pace of various changes, and the type and control of the emergent central guidance mechanisms. It is possible for international law and lawyers to influence the process by which these uncertainties get resolved and even to accelerate the transition to a new system of world order.

This article supports the proposition that international law and lawyers can play a significant and beneficial role during this period of transition, but only if they become sensitive to the wider process of change underway in international society and, more controversially, if they give self-conscious support to a set of explicit world order goals that structure both the means and the ends of transition. Sir Paul Vinogradoff provides a touchstone for my theme. In the course of arguing that a comparison among various historical types of international law is necessary to achieve an understanding of "what is

- This article is a revision of material originally delivered as the Sherrill Lectures at Yale University, March 1974.

$\dagger$ Albert G. Milbank Professor of International Law and Practice, Princeton University. 
essential and what is accidental in the transformations of law,"1 he eloquently describes the potential role of the international lawyer:

In this quest for the spirit of the laws we are certainly not animated by fatalistic resignation. As knowledge of the laws of nature does not deprive men of the possibility of turning them to profit, so the logical force of ideas does not condemn societies to go adrift under the sway of currents of opinion .... [F]ar-seeing guides, determined leaders, fruitful workers are no less necessary in the outward social movement than are explorers, inventors, wellequipped craftsmen in the material world. The best vessel may be the victim of shipwreck, but it is the pride of free men to oppose danger by farsighted and stubborn efforts. ${ }^{2}$

I believe it is possible for international lawyers to contribute to the work of constructing "the best vessel" to which Vinogradoff refers us, but their contribution is by no means assured. Indeed, international law and lawyers often follow prevailing lines of power and wealth; in the current context this tendency would serve to accentuate the deficiencies of the old system and encourage the emergence of a regressive variant of central guidance. That is, unless international lawyers become actively conscious of the positive central guidance options that exist, their principal role will be to serve those international actors who currently control behavior and who are characteristically tending toward exploitative and dangerous patterns of adaptation to the mounting transitional pressures.

It is important not to exaggerate the prospects even for enlightened approaches. Even aside from the question of gaining influence, those with an enlightened view may still not accomplish much. As Vinogradoff suggests, even the best vessel may fall victim to shipwreck. The dimensions of our juridical ship mainly reflect the anthropological, social, economic, political, and technological circumstances that together constitute an historical context. If we are to have any realistic prospect at all of reshaping this context, we must accurately appreciate the constraints as well as the options.

1. Vinogradoff, Historical Types of International Law, 1 Biblotheca Visseriana 8 (1923). See J. BRIERLY, The Basis of Obligation in International Law, in THE BASIS of Obligation in International Law and Other Papers by the Late James Leslie Brierl, $x^{\prime}$ I, 2 (H. Lauterpacht \& C. Waldock eds. 1958):

There is a subtle interaction between theory and practice in politics, not always easy to trace because the actors themselves may easily be unconscious of their theoretical prepossessions which, nevertheless, powerfully influence their whole attitude towards practical affairs; and at no time has it been so important, as it is today, that we should see the facts of international life as they really are, and not as they come to us reflected in false or outworn theories.

2. Vinogradoff, supra note 1. 
An intriguing passage appears in Henry Kissinger's Harvard dissertation:

The success of physical science depends on the selection of the crucial experiment; that of political science in the field of international affairs, on the selection of the "crucial" period. I have chosen for my topic the period between 1812 and 1822, partly, I am frank to say, because its problems seem to me analogous to those of our day. ${ }^{3}$

I agree with Mr. Kissinger that insight into the present situation can be gainfully achieved by a careful study of a relevant historical period. However, I believe that Kissinger, along with many others of his generation, has chosen the wrong historical analogy. The reason for choosing the 19th century is obvious. It was a time when an international aggressor, Napoleonic France, was successfully neutralized by a coalition of conservative states through a diplomacy that constructed a relatively stable system. In Kissinger's view, the problem of our age, perhaps of any age, is to prevent revolutionary actors from mounting a challenge against the existing order. In our age, this objective has involved confronting first Hitler's Germany, then the Soviet Union and most recently, the Third World. Succinctly put, Kissinger's utopia is stability. 4

It is my judgment that, although the 19th century analogy (or, to use a 20th century term, the "Munich lesson") is an important one for policymakers to study, far more important is the analogy which can be drawn from the 17 th century transition to the modern state system. In effect, the transition analogy can help us to fashion the "major premise" on which to base a viable strategy of global reform. As I see it, the tragedy of our age is that the leaders of many countries, including our own, act as if the minor premise of deterring aggressors were the major premise of building a post-nation-state system of world order. Such leaders act, moreover, as if the major premise reflected nothing more substantial than wild musings or wishful thinking.

The world order shift now underway seems to be a reversal of the shift completed in the middle of the 17th century, by which time Medieval Europe had given way to the modern state system. The 17th century completed a long process of historical movement away from nonterritorial central guidance and toward territorial decentralization,

3. Quoted in S. Graubard, Kissinger: Portrait of a Mind 10 (1973).

4. Kissinger's main academic works dwell on this central theme. Perhaps it is most fully and starkly depicted in his principal works on contemporary international relations. See The Necessity for Choice: Prospects of American foreign Policy (1961); Nuclear WeApons AND Foreign POLICY (1957). 
whereas the contemporary transition process seems headed back toward nonterritorial central guidance. In each context we shall consider the transition interval and try to identify some of the prefigurations of the future embedded in changing forms. Intimations of transition can be found in many elements of cultural expression. Indeed, it is the artists who often are the first to express the handwriting on the wall.

The transition interval is one during which elements of the new system intermingle with elements of the old. It may go on for several centuries. Its boundaries are often the subject of prolonged scholarly dispute. Even its reality may be controversial, at least until established in retrospect. Beyond all doubt developments occur unevenly. There were European territorial states in existence long prior to Westphalia; for example, England possessed most of the features of a territorial state from the 13th century onwards. Indeed, one specialist writes that "[b]y 1300 it was evident that the dominant political form in Western Europe was going to be the sovereign state." 5 But what this historian had discerned was only an incipient tendency, one which subsequently accumulated momentum over a long period of time. The state is the main building block of "the state system," but its existence did not assure the emergence of the specific pattern of international relations that began to take shape in the 17 th century. For this reason it remains valid to associate the origins of the modern state system with the Peace of Westphalia, with the understanding that such a generalization is a focusing device to bring broad patterns of change into clear delineation, at the cost of blurring details.

In this spirit of seeking to grasp world order patterns, and more especially the characteristics of a transition period during which one pattern gives way to another, I will pose several main questions that help focus inquiry into the role of international law and international lawyers. What can we learn from this prior transition process which culminated in the birth of the state system? What roles were played by international law and lawyers? To what extent is this historical experience transferable to the present transition context? How can international law and international lawyers help assure the emergence of a new post-state system of world order that is relatively more peaceful and just? Does the participation of international lawyers depend upon their national, ideological, cultural, socio-economic locus of concerns? Is it possible to formulate a position on the means and ends of transition that could serve as the basis for a transnational or global consensus

5. J. Strayer, On the Medieval Origins of the Modern State 57 (1970). 
and thereby provide the normative grounding for a political movement dedicated to global reform? This article responds to such questions, to some more directly than to others, but with the overall objective of helping to formulate a world order ideology appropriate to human needs and aspirations, given the present historical situation of challenge and opportunity.

It may be helpful to set forth the main elements of my argument at the outset:

(1) The state system is being superseded by a series of interlocking social, economic, political, technological, and ecological tendencies which are likely to eventuate in some form of negative utopia, i.e., in a very undesirable and dangerous structure of response to the problems posed by the deepening crisis in the state system.

(2) Although this disquieting outcome seems probable as of now, it is not inevitable. There is also a positive option premised upon an affirmation of the wholeness of the planet and the solidarity of the human species that could bring about a rearrangement of power, wealth, and authority that would be more beneficial than anything the world has heretofore known. ${ }^{6}$

(3) Initially, the global reform movement needed to promote such a positive outcome has to take principal shape outside of and mainly in opposition to the centers of constituted political and economic power: it will almost certainly have to be populist and antigovernmental in character and origins. ${ }^{7}$ Such a movement should be premised upon nonviolence to the extent possible.

(4) The principal initial focus of a movement for positive global reform should involve education-for-action, that is, a demonstration that the felt needs and frustrations of people in a variety of concrete social circumstances around the world arise from the inability of governments or the existing multinational actors to find short-range, middle-level, and long-range solutions to the distresses and dangers of our world. ${ }^{8}$

(5) The case for global reform should be premised on a basic as-

6. In actuality there is a cluster of organizational options that follows from the adoption and implementation of an orientation toward global reform that accepts the ecological and ethical premises specified in the text. See R. Falk, A Study of Furure WorLds (1975).

7. Fouad Ajami specifies the contours of such a movement in a stimulating paper. The Global Populists: Third-World Nations and World-Order Crises (Princeton Univ. Center of Int'l Studies, Research Monograph No. 41, May 1974).

8. Rethinking the attachment of people to the state is one essential element in fashioning an adequate strategy of response to world order challenges. In this regard, see Schaar, Power and Purity, 19 AMr. REv. $162-79$ (1974); Schaar, The Case for Patriotism, 17 AM. REv. $59-99$ (1973). 
sessment of structural trends and options. It need not rest altogether on the collision course that apocalyptic reformers are conveniently programming to take effect around the year 2000. ${ }^{\circ}$ We should be somewhat suspicious about the recent show of millennial egoism, the notion that we either change by the year 2000 or everything is lost. ${ }^{10}$ There is a temptation to deliver an apocalyptic sermon to the wayward citizenry of Nineveh, but such a message would probably be shaped by the characteristic desire of mortals to witness the completion of their own reform projects within the compass of their probable lifetimes. My inclination is to adopt the perspective of that retired French general who wanted to plant in his garden some species of trees that he had grown to love during his years of service in an Asian country. When told by his gardener that such trees would not blossom for 70 years, long after his death, the general is supposed to have said, "In that case, don't wait until after lunch to plant them."

Can international law and lawyers play a significant role in relation to a credible strategy of global reform? The language and sensibility of law tend to be static. New modes of thought, new orientations are needed if law and lawyers are to achieve a dynamic, processive perspective. Such an outlook is obviously essential to the whole idea of a transition process in the course of which the very framework of legal relations would undergo fundamental change. Can we develop an interpretation of that transition process that international lawyers can use to analyze the main developments of international life that call for the application of legal techniques such as negotiation, adjudication, treaty-making, and institution-building? Without such an interpretation the characteristic problems of the day-whether they be the status of prisoners of war, claims to impose or disrupt an oil embargo, the status of military reprisals, or satellite surveillance-are fed back into an obsolete framework of interstate relations where the irrelevant cynicism of the Machiavellians jousts with the irrelevant moralism and legalism of the idealists. We do not need judgments of approval and disapproval nearly as much as we need a set of values that can inform a strategy of change. What was "realism" a generation ago when the state system was able to deal adequately with the main problems of the day becomes "crackpot realism" in the current world setting. Regardless of our normative outlook, we require a new framework to comprehend the dynamics of global transformation.

9. See, e.g., B. Commoner, The Closing Circle (1971); P. Ehrlich, The Population Bомв (1968).

10. See Lewis, Oil, Other Scarcities and the Poor Countries, 27 WordD Polrtics 63-86 (1974). 
It is my hope that this new framework can perform a social and political, as well as an intellectual role, by helping to mobilize a normative consensus that challenges the prevailing ethical currents of neoDarwinian sentiment and policy. As matters now stand, the process of transition is being dominated by those who believe that the privilege of the few in the face of the misery of the many is either inevitable or actually beneficial, providing a necessary foundation for human excellence and accomplishment. The central feature of the normative challenge that I would propose as a counter rests upon an acceptance of human solidarity and all of its implications, especially a shared responsibility to seek equity and dignity for every person on the planet without regard to matters of national identity or territorial boundary.

Since the 17th century the territorial state has been the principal organizing unit in global politics, and national governments have been the principal actors. Modern international law arose to give juridical expression to this political reality. ${ }^{11}$ It was a political reality that began to take shape in medieval Europe, but subsequently assumed global significance, through a combination of Western superiority over other regional systems of organization, and the actual physical colonizing and missionizing processes that managed to extend the sway of this Eurocentric system over most of the rest of the world. That is, there are other regional systems of multistate law, but none whose claims of universal applicability achieved such plausibility as a result of the extension of actual influence beyond the region of its origins. ${ }^{12}$

Since Grotius, if not before, this juridical consensus has provided international lawyers with a generally shared framework. ${ }^{13}$ To trans-

11. There are as many types of international law as there are distinct types of political reality. And, indeed, if states become less predominant in managing global relations, then we would expect a new legal order in which other actors played more significant actual and formal roles.

12. See B. Röling, International LAw in AN Expanded World (1960), For fuller discussion of the legal traditions active in maintaining interstate order in other regions of the world, see A. Bozeman, THE Future of LAw in a Multicultural World (1971); $F$. Northrup, The Taming of Nations (1952).

13. It was Grotius, however, who set forth the normative foundations for a world of separate territorial sovereignties with distinct claims of autonomy, in a major treatisc on the relevance of law to war. See H. Grotius, The Rights of WAR AND PEAcE (A. Campbell transl. 1901). The essence of the modernist element in Grotius was his refusal to recognize a decisionmaker higher than the head of state, or an interpreter of legal obligation other than that head of state. Even though he believed that Iegal rules have an objective character, he regarded their application as dependent on subjective appreciation by juridically equal state leaders. For an analysis of thinkers who antedate Grotius such as Vitoria, Suarez and Gentili, see P. CoRbetr, Law and Society in the Relations of States 17-24 (1951); A. Nussbaum, A Concise History of THE LAw of Natrons 79-10I (rev, ed. 1954). 
form it will require a new perception of a changing political reality, and an awareness that the juridical articulation of the perception can influence the balance of choice among historical options, as well as condition the moral quality of the prevailing option. Vinogradoff understood that while not all options are historically plausible, neither is there an inevitable historical current that predetermines the world order outcome. Some human pressure on the rudder at the right moment may avert collision, or even assure that the voyage is a pleasant one. What I am arguing is that international legal studies remain, by and large, ignorant of the system-changing context, and that we compound the tragedies in store for us by not fashioning a new juridical expression which corresponds to the political realities that are moving the world system from one of relatively decentralized, if hierarchically arranged, statism to relatively centralized, but not yet predetermined, rearrangements of managerial control and value priorities.

Thomas Kuhn has attracted considerable attention through his depiction of the structure of scientific revolutions. His basic observation, relevant to our purposes, is that natural scientists at any given time work within a paradigm of shared assumptions, traditions, and procedures, to solve the characteristic problems confronting their profession. Kuhn describes a paradigm as "universally recognized scientific achievements that for a time provide model problems and solutions to a community of practitioners." ${ }^{14}$ Such a paradigm sets boundaries on research and creates a set of intellectual taboos that prevail until challenged by new discoveries, so-called anomalies, that are not explicable within the reigning paradigm and yet appear too significant to ignore or disavow. ${ }^{15}$ It is at such a point that a scientific revolution occurs and a new paradigm is crystallized, in order to allow the work of the profession to proceed with maximum efficiency because a large fundamental area of agreement can again be taken for granted.

Kuhn has been properly critical of facile extrapolations of his ideas

14. T. Kuhn, The Structure of Scientific Revolutions viii (2d ed. 1970). Later Kuhn defines a paradigm as follows: "A paradigm is what the members of a scientific community share, and, conversely, a scientific community consists of men who share a paradigm." Id. at 176. He distinguishes between two different senses in which the term "paradigm" is used: "On the one hand, it stands for the entire constellation of beliefs, values, techniques, and so on shared by the members of a given community. On the other, it denotes onc sort of element in that constellation, the concrete puzzle-solutions which, employed as models or examples, can replace explicit rules as a basis for the solution of the remaining puzzles of normal science." Id. at 175 .

15. Id. at 97 . During a period in which a paradigm is securely cstablished, the boundaries of what constitutes knowledge are firm. Claims to discovery or explanation beyond such boundaries are repudiated or ignored, and claimants regarded as deviants. Indeed, when questions are posed and taken seriously involving the broad issue-"what is knowledge?" - then it is a sign that a paradigm is loosening its hold on a given scientific community. 


\section{A New Paradigm for International Legal Studies}

about paradigms in the natural sciences to the disciplines of social science. Indeed, he contends that the social sciences operate without a paradigm of shared perspectives, in the sense that he applies the term to the work of physics, astronomy, biology, and chemistry. ${ }^{16}$ With respect to international law, however, I think there has been a paradigm present, certainly not as explicit as the one which has normally guided astronomers, but nevertheless a paradigm that confines inquiry and embodies a consensus as to the political terrain upon which international law can fruitfully operate. By looking back at pre-modern types of international law we can discover that the statist paradigm has not always dominated inquiry, that a major juridical revolution in this direction was largely accomplished by the work of Grotius and consolidated by Vattel. ${ }^{17}$ The statist paradigm has been used by the profession to discipline deviant practitioners, mainly by labelling them as "utopian," "legalist," or "idealist," that is, as unworthy of serious attention because they worked outside the paradigm, or more likely, challenged the prevailing paradigm of geopolitically conditioned interstate relations. ${ }^{18}$ (Occasionally, statist deviants have also been disciplined by being called "cynics" if they went too far in denying the role of law in world affairs. ${ }^{19}$ ) At the present time, in my judgment, we are on the verge of another juridical revolution of the sort Grotius accomplished, but this time the revolution will dethrone rather than legitimate the statist paradigm and put in its place a framework based on some form of central guidance.

There are several characteristics of a paradigm shift. First, it is a

16. Id. at viii.

17. E. de Vattel, The law of Nations, or Principles of the Law of Nature, Applied to THE Conduct AND AfFairs of Nations and Sovereigns (J. Chitty transl. 1855). Hedley Bull correctly notes that in this century there has been a resurgence of Grotian thinking and a relative decline in the stature of Vattelian thinking. Professor Bull laments this resurgence as he associates it with an immoderate or revolutionary phase in international relations. Bull, The Grotian Conception of International Society, in Diplomatic Investigations $51-73$ (H. Butterfield \& M. Wight eds. 1966). I interpret this resurgence of Grotian thinking more favorably, as disclosing a growing juridical sentiment for the reform of international relations in the face of mounting evidence of the inability of the statist paradigm (especially in its purer Vattelian form) to mect the main concerns of humankind.

18. See, e.g., G. Kennan, American Diplomacy 1900-1950 (1952); H. Morgenthau, Dilemmas of Politics (1958); H. MoRgenthau, IN Defense of the National Interest (1951). For critical remarks about the influence of lawyers and legal background on the approach of American policymakers to the foreign policy process, see $H$. KISSINGER, American Foreign Policy: Three Essays 29-34 (1969). Kissinger notes, inter alia, that one consequence of what he calls "the Anglo-Saxon tradition" is that lawyers or legálly trained individuals "prefer to deal with actual rather than hypothetical cases; they have little confidence in the possibility of stating a future issue abstractly." Id. at 30 .

19. See Louis Henkin's discussion of Dean Acheson's deprecation of the role of international law in geopolitical crises (in that instance, the Cuban Missile Crisis). L. HenkiN, How Nations Behave 265-66 (1968). On the general issue of law and its limits, see id. at 251-71. 
mutation rather than a series of increments. Second, it embodies a coherent explanation of the entire agenda of problems relevant for a current generation of practitioners. Third, if cultural issues are involved, then the paradigm shift will occur in many disparate fields of experience, such as art, science and the humanities. ${ }^{20}$ The idea of a paradigm shift (or system-change) needs to be underlined because it is particularly uncongenial to the American temperament. This concept is especially uncongenial to American lawyers who tend to view constructive social change as necessarily incremental and who distrust overall explanations of complex social and political phenomena.

But my reason for urging consideration of a new juridical paradigm is quintessentially American: namely, that the old juridical paradigm no longer "works," that it no longer seems responsive to the main problems on the international agenda. Thus those who persist in carrying on their inquiries within the old paradigm end up with trivial results, because either they work on irrelevant problems or they work on relevant problems with an inappropriate procedure. Of course, so long as the old paradigm works it is sensible to take it for granted so that we can concentrate our efforts on the frontiers of knowledge. ${ }^{21}$ The more we can safely take for granted, the greater proportion of our time and energy we can devote to that which is not yet adequately understood. The problem in a period of transition is that we are no longer justified in taking very much for granted and, therefore, we have to create a new superstructure that "works" for the problems we seek most to solve.

To create a foundation for this line of interpretation I wish to look back at the pre-modern paradigm that existed in medieval Europe, and then at that twilight transition period when the old paradigm was crumbling, but a new one had not yet definitively crystallized. Of course one can always find antecedents, whether for scientific or juridical revolutions, which make boundary markers appear somewhat arbitrary. For instance, one leading interpreter of the origins of the modern state concludes that the process by which this new organizational form came into being was completed by the year 1600 , or almost 50 years before the Westphalia treaties. ${ }^{22}$ But our concern is with the

20. See Gebser, The Foundations of the Aperspective World, 29 MAIN Currents 80, 81 (1972).

21. Alfred North Whitehead has a concise formulation for this point: "It is legitimate (as a practical counsel in a short life) to abstain from the criticism of scientific foundations so long as the superstructure 'works.'" Principle of Relativity, in Collected Works OF AlFRed NORTH WhitehEad 300 (M. Gross \& F. Northrup eds. 1953).

22. J. STRAYER, supra note 5 , at 10 , dates the process of statist consolidation as between 1100 and 1600 . But cf. Edmund Burke's contention that "the generality of people are fifty years, at least, behindhand in their politics." EDMUND BURKE: SELECIED WRITINGS AND SPEECHES 107 (P. Stanlis ed. 1963). 
state system as distinct from the medieval system, rather than with the process by which the elements of the system were formed. Since politics is a consensus-building compromise-oriented realm, there is a strong tendency by actors to keep the paradigm shift implicit, even disavowed, until long after it has been effectively accepted as conventional wisdom. In the history of international law, the writings of jurists, the great lawmaking treaties, and the contending positions (or claims) of antagonists in the most prominent legal disputes of a given period all manifest an ambivalence toward the contending paradigms. Dual loyalty to the past and to that which is still to come injects an element of incoherence in these three characteristic settings of international law activity during any period of transition from one world order system to another. Indeed, the existence of such incoherence is, perhaps, one of the strongest indications that a particular historical period is actually undergoing transition.

A further feature of a transition period is an attitudinal shift toward interpretations which challenge the dominant paradigm..$^{23}$ While the dominant paradigm is secure, deviant interpretations, other things being equal, can be ignored, or virtually so, as harmless. But as evolving events undermine the older paradigm's claim to deal adequately with the problems within its domain, new claims based on an alternative paradigm begin to be perceived as credible challenges. The guardians of the status quo begin to perceive deviant interpretations as dangerous, rather than as merely silly. In effect, previously harmless knowledge becomes dangerous knowledge. In this vein, it is worth noting that Grotius's treatise, undermining the medieval unity and the special role of the Pope, was placed on the Papal Index in 1626 and was not removed until $1899 . .^{24}$

In writing of the emergence of the modern statist paradigm, James Turner Johnson notes, with special reference to the changing status of war, that "were only the Spaniards thinking along these lines, the new order would never have emerged; its genesis and growth derive not only from changed historical circumstances but also from fairly widespread efforts to think out the implications of these changed conditions with the help of natural law considerations." 25 That is, threshold phenomena such as the Grotius treatise and the Peace of Westphalia are reflections of an emergent, widely shared, disparately formulated

23. T. KuHN, supra note 14 , at $52-76$.

24. A. NusSBAUM, supra note 13, at 114, observes that Grotius's treatise was placed on The Index "with the mitigating though practically insignificant proviso 'donec corrigatur" (until amended)."

25. J. Johnson, Ideologx, Reason and the Limitation of War (forthcoming 1975), (typescript at 126). 
consensus regarding changed conditions and their juridical consequences. As Professor Johnson points out, not only Grotius and his Spanish antecedents, but a whole tradition of English speculation, perhaps best represented in the writing of Matthew Sutcliffe ${ }^{26}$ and William Ames, ${ }^{27}$ was formulating a similar set of juridical interpretations from premises set forth in the great philosophical treatises of Hobbes and Locke. ${ }^{28}$ In other words, for a juridical revolution to occur, there must be a convergence of interpretations based on intersecting perspectives drawn from the main interacting directions. ${ }^{29}$ By the time the new juridical paradigm exists unambiguously, probably it has largely passed already into conventional wisdom.

Let me now briefly consider the juridical paradigm shift that accompanied the wider historical transition from the Middle Ages to the modern world. We are concerned here with the profound effects on the substance and methodology of international law that can be attributed to the emergence of a new world order system at the end of the Middle Ages. We are concerned also with the role that jurists and juridical events seem to have had in accelerating and shaping the new paradigm embodied in the dynamics of the state system. My purpose is not to achieve a new historical understanding of the origins of modern international law, a much debated and rather unimportant question. My purpose is rather to prepare the ground for studying the actual and potential relevance of international law to the current transition from the state system to some form of central guidance.

The main world order transition of the 17th century involved the substitution of a relatively multipolar state system for the former relatively unipolar imperial system bound together by the authority of the Pope and the spiritual unity of Christendom. ${ }^{30}$ The medieval system was one in which papal central guidance was coordinated with feudal loyalties to family, church, guild, and prince. The claim, as crystallized in 1075, was one of supremacy for the Pope, "that his decision ought to be reviewed by no one, and that he alone can review the decisions of everyone; that he ought to be judged by no one."31 Joseph Strayer

26. M. Sutcliffe, The Practice, Proceedings and Law of Armes (1593).

27. W. Ames, Conscience with the Power and Cases Thereof (1643).

28. J. Johnson, supra note 25.

29. At the same time, a diversity of interpretations of the juridical situation is evidence that a paradigm shift is underway and such a diversity, which generates confusion and controversy, is characteristic of a transition period.

30. The political realities of medieval times were complicated and dominated by the character of highly localized power arrangements. In this regard, notions of Papal supremacy and spiritual unity were rhetorical more often than behavioral, and should not, in any event, be accepted uncritically.

31. Articles 18-19 of Dictatus Papae Gregorii, translated in E. Lewis, Medieval PolitICAL IDEAS 381 (1954). 
also refers to the more compact formulation of Innocent III that Popes "judged all and could be judged by no one." 32 In contrast, the modern state is characterized by spatial boundaries sustained through time, by a set of specialized administrative institutions, and by what Strayer calls "[t]he final, most important, and most nebulous of our tests," that is, "a shift in loyalty from family, local community, or religious organization to the state and the acquisition by the state of a moral authority to back up its institutional structure and its theoretical legal supremacy." 33

It is the antagonism between these two sources of moral authority that characterizes the transition period from medieval Europe to the modern state system; and it is the eventual dominance of statist ideology that marks the end of transition and the beginning of the statist era. This antagonism was personified by the struggle between the Papacy and Philip IV of France, who reigned over one of the earliest political units to achieve statehood in the modern sense. The controversy was provoked by Philip's efforts to tax the French clergy without prior consent from Rome. The reigning Pope, Boniface VIII, considered this an improper attempt to subject the Church to secular control. It led to the famous papal bull Unam Sanctam in 1302 which has been described as an effort "to sum up and define the plenitude of the Papal power over all the Christian community, including France and her king." ${ }^{4}$ It expressed the pure ideology of the medieval system in its first self-conscious confrontation with paradigmatic threats from emergent state units. Unam Sanctam staked out a claim of a once single ascendant Church: "At the time of the flood there was, indeed, one ark of Noah, prefiguring one Church; it ... had one steersman and commander, namely Noah, and we read that outside of it all things existing on earth were destroyed." 35 From this unity springs a hierarchy of authority, rather than two equal swords of temporal and spiritual authority: "Spiritual power exceeds any earthly power in dignity and nobility, as spiritual things excel temporal ones.... If, therefore, earthly power err, it shall be judged by the higher, competent spiritual power, but if the supreme spiritual power err, it could be judged solely by God, not by man." 36 Thus, the temporal authority of a king is derived ultimately from the same unity as the Church, but its claims

32. J. STRAYER, supra note 5 , at 8 (especially note 2).

33. Id. at 9.

34. Church and State Through the Centuries 89 (S. Ehler \& J. Morrall eds. \& transls. 1954). (The full text of Unam Sanctam appears in English at 89-91.)

35. Id. at 90 .

36. Id. at 91-92. 
are subordinate to those of the Pope, who is the supreme spiritual authority on earth. ${ }^{37}$

It is significant that Philip's views prevailed and that he repudiated the Papacy. But this seed of statism would take several centuries of growth before its full flowering would occur. Perhaps the best crystallizations of this changeover to the state system are not to be found until the Peace of Westphalia, regarded as the decisive juridical event, and Grotius's treatise The Rights of War and Peace, regarded as the decisive juridical formulation. ${ }^{38}$ In both instances, the transition context is clearly evident from the way in which the forms of the eroding order are drawn upon so as to embellish, and perhaps disguise, the substance of the new order. Peace treaties had been, heretofore, the decisive juridical events in international history, because the search for an acceptable political framework within which to manage international conflict has been almost exclusively concerned with the problem of war and peace. The system-changing peace treaties, a small subset, have been those which marked major shifts in managerial conceptions, by altering authority patterns, by staking out new roles for actors, or by expressing a new awareness of the destructiveness of warfare and a temporary determination to cooperate to the extent necessary to keep the peace.

Consider the Peace of Westphalia from this perspective. It took almost four years to negotiate, and when finally concluded in 1648, it formally brought the Thirty Years War to an end. The treaty carried forward notions of territorial absolutism on matters of religious preference (at least within the Christian regional system) and removed the issue of religious faith from the list of just causes for which a prince might have recourse to war. ${ }^{39}$ The Church could no longer stand above the secular fray and serve as an impartial arbiter among Christian foes, nor could it form an alliance with the Holy Roman Emperor. Thus the Peace of Westphalia signalled the shift in the locus of power that accompanied the rise of strong territorially based nation-states, acknowledging the split in Christendom that led to the Reformation, and then to the Counter-Reformation. The Thirty Years War involved a final defeat of the effort by the Hapsburg Dynasty to reestablish the secular and spiritual unity of pre-Reformation Europe. It thereby assured the

37. The dispute was part of the process that led to the temporary shift of the seat of the papacy to Avignon.

38. A. Nussbaum, supra note 13 , at $112-14$, 115 . See H. Grotius, supra note 13.

39. The principles of religious tolerance had already been anticipated in 1555 in the Peace of Augsburg. Id. at 116. But this anticipation was on an intra-German, rather than at an international, level. 
decentralization of power and authority which has become one major attribute of the state system. Recall our earlier contention that harmless knowledge turns to dangerous knowledge as the hour of paradigm shift approaches; it is revealing that Pope Innocent $\mathrm{X}$ condemned the provisions on religious tolerance, the very core of the Peace of Westphalia, as "null, void, invalid, wicked, unjust, condemned, reprobated, futile, and without strength and effect" in the Papal Bull Zelo domus Dei of November 20,1648.40 The Bull even purported to nullify the oaths made to carry out the treaty; significantly, the treaty was carried out in all its parts, and the papal intervention seemed to exert no influence even on the Catholic rulers who had signed the treaties at Munster and Osnabrück. Nussbaum aptly notes: "Just as there is a spiritual nexus between Grotius's work and the Peace of Westphalia, so there is a similar nexus between the papal condemnations of Grotius's work and of this Peace." 41 And so those who are the bearers of a new paradigm for international legal studies can expect similar harsh treatment.

The military outcome of the final phases of the Thirty Years War also reflected the rise of secularized geopolitics, as Catholic Bavaria allied with Lutheran Sweden to oppose the Hapsburgs while the French Catholic monarchy supported the essentially Protestant effort to halt the Counter-Reformation. Thus, a perceived need to check secular ambitions was a significant element of the pre-Westphalia alliance system, notwithstanding the prevailing rhetoric by which the participants insisted on emphasizing the religious stakes of the conflict. Put differently, Catholic France would undoubtedly have preferred to see Catholicism restored throughout Europe, but not at the cost of making the Hapsburg Empire the dominant actor in Europe. Rather than acquiesce in such a disadvantagous geopolitical situation, France was prepared to help the anti-Catholic cause prevail in the Thirty Years War. The principal loser in the Thirty Years War was the loosely confederated German empire. ${ }^{42}$ After Westphalia, it was France that emerged as the most powerful actor, mounting expansionist drives in subsequent periods to achieve hegemony over the whole of Europe, first under the aegis of Louis XIV and later under Napoleon. These efforts resulted in the two most important peace treaties after 1648-

40. Church and State Through the Centuries, supra note 34, at 196. (The entire text of the Bull appears at 193-98.)

41. Id. at 116.

42. "Culturally and economically the war had thrown Germany back more than a century. She had lost one-third of her population according to conservative estimates. To this the Peace added the irretrievable paralysis to the Empire's political might." A. NussBaUM, supra note 13 , at 116 . 
the Peace of Utrecht (1713) and the Peace of Paris (1814, 1815), related to the Congress of Vienna. These treaties manifest a second attribute of the state system, the increasingly self-conscious use of alliance relationships to sustain the multipolarity of the world order system and to contain revolutionary actors who seek a large-scale revision in basic geopolitical relationships.

At Westphalia there was a realization that in some national societies there were domestic religious differences, and that unless these differences were tolerated they would cause civil strife and generate pretexts for intervention by outsiders. Therefore, the treaty protected the religious conscience of individuals while reinforcing the new peace framework of sovereign states; it thereby also expressed the philosophy of natural rights underlying the contemporary development of an international law of human rights. ${ }^{43}$ In the setting of the 17 th century this right of personal choice, accompanied by an ethics of toleration, reflected the growing influence of an individualistic ethos which had many roots, ranging from the rise of capitalism to the whole notion of enlightenment and individualism associated with the Renaissance, and extending to the Luther-led revolt on behalf of conscience against the arbitrary authority of the Church.44

Thus Westphalia embodies one of those "omnipresent complementarities," as Professor McDougal calls them, in the prevailing international legal order ${ }^{45}$-on the one side, matters of religion are confined to domestic jurisdiction; on the other, abridgments of religious freedom are made matters of international concern. The tension between domestic jurisdiction and human rights is as old as the persecutions of the Huguenots or Puritans and as contemporary as the persecution of Soviet Jewry. It remains necessarily ambiguous in each context whether deference to state sovereignty should take precedence over efforts to rescue victims of governmental abuse.

Here, then, are the major elements of the modern state system prefigured in the Peace of Westphalia, although rendered somewhat murky in its express language by the residual deference to and reliance upon the outmoded system that was being supplanted. It is this ex-

43. This concern with the individual or group is an alien element in a purely statist conception of international society. It is like a dormant bacteria that waits for the organism to weaken before it mounts an attack. The natural rights feature is significant because it underscores the inalienable character of fundamental human rights, thereby assuring their legal status independent of expressions of consent by governments. See note 56 infra.

44. This revolt, although triumphant in a politically conservative form, is one of the most significant elements of revolutionary energy present in the Protestant movement as a whole.

45. McDougal, The Ethics of Applying Systems of Authority: The Balanced Opposites of a Legal System, in THE ETHIC OF POWER 221, 222 (H. Lasswell \& H. Cleveland eds. 1962). 
hibition of transitional intersystemic confusion that is especially interesting for our purposes. First of all, the secularization of international politics is disguised by the adoption of a highly religious rhetoric characteristic of a much earlier mood. The use of this rhetoric may have expressed a measure of nostalgia, and it may indicate a perfectly reasonable attempt to use the shared Christianity of the opposing leaders as a normative common ground above their ecclesiastical divisions. Article I of the Treaty of Westphalia (Munster) expresses this tone:

[T]here shall be a Christian and Universal Peace, and a perpetual, true, and sincere amity, between his Imperial Majesty and his most Christian Majesty. ${ }^{40}$

There are also numerous indications of the residual role of feudal arrangements even at the level of intergovernmental compacts. Indeed, the older feudal paradigm provided a ready-made means of implementing the conflict's main geopolitical outcome, the defeat and frustration of the Hapsburg design to extend the sway of the Holy Roman Empire over the numerous Germanic principalities. The Peace of Westphalia conferred autonomous international status on the more than $300 \mathrm{mem}$ bers of the Holy Roman Empire; they were given the legal capacity to enter alliances with foreign governments and to wage war, provided only that the alliances were not directed at the Empire or against the terms of the Peace of Westphalia. These subordinate units of empire "were thereby lifted to an international legal status approximating sovereignty though the old term Landeshoheit (territorial supremacy) was preserved." 47 Here, too, we note ironically another characteristic

46. 1 Major Peace Treaties of Modern History 9 (1967) thereinafter cited as Major Peace Treaties]. (The entire Westphalia text appears at 7-49.)

47. A. Nussbaum, supra note 13, at 116. Even the language of the treaties is replete with feudal terminology; for instance, in the general amnesty provision, Article VI, we note references to "their Lordships, their fiefs, Underfiefs, Allodations" and to their "Dignities, Immunities, Rights, and Privileges." I MAJOR PEACE Treaties, supra note 46, at II. In confirming French royal sovereignty over towns in Alsatia and Sungtau Article LXXVI refers to "all the Vassals, Subjects, Peoples, Towns, Boroughs, Castles...." Id. at 31 .

In the Westphalia Treaty there is an acknowledgment not only that national governments are the main participants in the new world order system, but also that such governments are not the only participants. This view contrasts to that of the late 19th and early 20th century, a view that is itself now coming under some pressure. The view that governments of states are the only participants finds its way into some of the most influential earlier definitions of international law. See generally W. BISHOP, JR., INTERNATIONAL LAW 3-6 (2d ed. 1962). For a much wider appreciation of the participants in the world order, see McDougal, Lasswell \& Reisman, The World Constitutive Process of Authoritative Decision, 19 J. LEGAL ED. 253, $261-75$ (1967). The Munster variant of Westphalia included a long list of feudal allies of both principal signatories-The Holy Roman Emperor and the King of France-many of whom achieved great international status even though they could not qualify as states. 
feature of the state system: the primacy of geopolitics, especially the persisting effort by major governments to prevent any one of their number from achieving continental hegemony.

The closing articles of the treaty include some forward looking provisions involving an innovative effort to establish an agreed framework of restraint vis-à-vis recourse to war. For one thing, an effort is made to affirm the primacy of the peace obligation, even in the event that some aspect of the elaborate plan of "Restitution and Reparation" is not put into effect: "[A]ll Parties in this Transaction shall be obliged to defend and protect all and every Article of this Peace against any one, without distinction of Religion." 48 Even more impressive are the seeds of modern notions of peaceful settlement and provisions of an ambitious implementing procedure:

[A]nd if it happens any point shall be violated, the Offended shall before all things exhort the Offender not to come to any Hostility, submitting the Cause to a friendly Composition, or the ordinary Proceedings of Justice. ${ }^{49}$

Finally, the treaty contains a notion of collective security based on helping the victim of abuse, provided that victim has waited three years to allow settlement to come about by peaceful means.

[I]f for the space of three years the Difference cannot be terminated by any of those means, all and every one of those concern'd in this Transaction shall be oblig'd to join the injur'd Party, and assist him with Counsel and Force to repel the Injury, being first advertis'd by the injur'd that gentle Means and Justice prevail'd nothing.... ${ }^{\text {so }}$

The treaty also seeks to identify the "infringer of the Peace," what in modern parlance we call "the aggressor," as that party which first departs from the peaceful processes of settlement ("the means of ordinary justice"). ${ }^{51}$

Embedded in this threshold juridical event at Westphalia is a constitutional effort to lay down ground rules for a new status of war: at this point of transition the peace treaty became a legislative document seeking to prevent reversion to destructive warfare by taking account of

48. Article CXXIII, 1 Major Peace Treaties, supra note 46, at 46.

49. Article CXXIII, id.

50. Article CXXIV, id. at 47.

51. Id. 
"the new realities." My point here is that Grotius (and other jurists of the time) helped to formulate reformist notions on the status of war that were then translated by statesmen into a juridical formula that could be put into treaty form. International law also performed a critical role in providing a normative bridge between the spiritualist pretensions of the Middle Ages and the statist pretensions of the modern era.

Just as critics were unmasking the pious frauds perpetrated under the aegis of Church-centered normative guidance, ideologists of the state system were working out notions of absolute prerogative at the national level-often, as in the case of Bodin, so as to legitimate claims of domestic sovereignty on behalf of national governments that were opposed by feudal loyalists. ${ }^{52}$ The danger, of course, was that the collapse of Christian unity would produce a normative vacuum in which there were no shared guidelines of restraint. International lawyers provided an intricate set of procedures by which to uphold and maintain these shared guidelines in the new secular context, thereby moderating the abiding impulse toward amorality in interstate relations.

This contribution of international law and lawyers is easy to underestimate, especially as public attention tends to fasten on the spectacular struggles of the day in which all forms of constraint give way. But for recurrent and normal interactions among governments, and even for classes of interactions among antagonistic or warring governments, international law has provided a normative framework of immense practical value. This framework has been a constant buffer against more absolutist approaches to state behavior, and has refuted those simplistic assertions that rest the whole of international relations on considerations of relative military power. Thus, the role of the great international jurists in the Westphalian period was to add a beneficial normative element to the historical drift toward a statist option in international life. To be creative, in other words, required both an understanding of this historical drift, and an effort to exert an influence upon it.

The perspectives prefigured in Grotius and Westphalia became much more explicit in the Peace of Utrecht (1713) and in the prin-

52. Jean Bodin's principal work, The Six Bookes of a Commonweale (K. McRae ed. 1962), originally appeared in France in 1579. On the evolution and nature of sovereignty in the state system, see E. Cassirer, The MYTh of the State (1964); F. Meinecke, Machiavellism (D. Scott transl. 1957); R. Stereing, Ethics in a Wordd of Power: The Political Ideas of Friedrich Meinecke (1958). 
cipal treatise of Emmerich de Vattel. ${ }^{53}$ The main contractual undertaking at Utrecht was to formalize the frustration of Louis XIV's effort to extend French control to Spain in the War of Spanish Succession (1702-1713). In the treaty this result was expressed in the form of reciprocal renunciations by the French and Spanish kings of each other's thrones. ${ }^{54}$ What is more significant from our point of view is the more explicit emergence of the statist paradigm. First, territorial states are the prime actors; semi-territorial actors like the Holy Roman Empire or nonterritorial actors like the Pope have virtually no status. Second, geopolitics is explicitly acknowledged as an element of the international legal order. It is the means to sustain the multistate context, resist hegemony, and preserve balance; thus natural law perspectives on the status of war give way to balance of power perspectives. Third, governments are agents of their populations and spokesmen for their well-being; they exercise "that paternal Care which they delight to use towards their own subjects." 55

The geopolitical nexus of international relations is worthy of closer scrutiny. In several places, the idea that peace depends on geopolitical equilibrium is not only affirmed, but is practically elevated to a principle of natural law. ${ }^{56}$ In the Spanish king's renunciation of any claims on the French crown we find this phrasing:

[I]t being to be believed, that by this perpetual and neverceasing Hope, the Needle of the Ballance may remain invariable, and all the Powers, wearied with the Toil and Uncertainty of Battles, may be amicably kept in an equal Poise; it not remaining in the Disposal of any of the Partys to alter this federal Equilibrium by way

53. See note 17 supra.

54. I Major Peace Treaties, supra note 46, at 118 (describes major aspects of war).

55. Preamble to the Peace of Utrecht, id. at 177. "The Welfare of a People so faithful, is to us a supreme Law, which ought to be preferred to any other Consideration. It is to this Law that We this day sacrifice the Right of a Grandson, who is so dear to us; and by the Price which the general Peace will cost our tender Love, we shall at least have the Comfort of shewing our Subjects, that even at the Expence of our Blood, they will always keep the first place in our Heart." Renunciation of Spain to the Crown of France, Peace of Utrecht, id. at 184.

56. By "natural law" I mean that jurisprudential tradition which derives the authority of law and its fundamental content from sources of objective authority independent of human will. Among the varieties of natural law are those that rest their claim upon revelation by God, the dictates of reason, or the character of nature itself. What these diverse schools of natural law have in common is the assertion of a criterion of legality that takes precedence over any assertion by a particular person or any interpretation of an historical situation. Natural law is often set off against legal positivism, in which principal stress is placed upon deriving the authority and content of law from the consent of the sovereign or the operations of formal lawmaking procedures. See A. D'ENTREvEs, Natural Law (2d ed. rev. 1970).

Note that even at Utrecht the unity of Christendom remains an element in the settlement of conflict; parallel to this the relationship between the Christian and non-Christian world becomes an increasingly critical ethical and legal issue. 
of any Contract of Renunciation, or Retrocession; since the same Reason which induced its being admitted, demonstrates its Permanency, a fundamental Constitution being formed, which may settle by an unalterable Law the Succession of what is to come. ${ }^{57}$

Note here that solicitude toward subjects is given as a principal reason for preferring peace to a frequent assertion of unresolved dynastic claims, and that the permanent renunciation of such claims is intended to reinforce the equilibrium among the great powers, thereby discouraging renewal of war. International law provides governments with an authoritative instrument by which to solemnize such undertakings and to express the basis of peaceful relations in a definitive form that diminishes any prospect of future miscalculation. In another ancillary way, international law separates private grievances from public wrongs so as to provide remedies of a limited nature that do not threaten resumption of warfare. Thus, in Article XVIII it is agreed that if any subject of the contracting parties acts in a manner incompatible with the peace agreed upon, it shall not disrupt intergovernmental arrangements; "that Subject alone... shall suffer the Punishment, which is inflicted by the Rules and Directions of the Law of Nations." "58

The Peace of Utrecht manifests the full logical coherence of the new paradigm. The Christian bonds are still stressed, but not in an integral manner. Peace is sustained by geopolitical equilibrium, which requires two main things: first, secure boundaries and lines of dynastic succession; second, a realization that any attempt by a major power to

57. I Major Peace Treaties, supra note 46, at 187-88. The Declaration of Philip, Duke of Orleans, expresses a similar sentiment: "[I]t was necessary to establish a kind of Equality and Equilibrium between the Princes who were in dispute [regarding the prospect of Hapsburg succession to the Spanish Crown] .... [T] the Union of the Empire, would become formidable, if it should add a new Power to its ancient Dominions; and consequently this Equilibrium, which is designed to be established for the good of the Princes and States of Europe, would cease. Now it is certain that without this Equilibrium, either the States suffer from the Weight of their own Greatness, or envy engages their Neighbors to make Alliances to attack them, and to reduce them to such a point, that the great Powers may inspire less Fear, and may not aspire to an universal Monarchy." Id. at 199-200. This statement resolves Spanish succession in an indisputable fashion, confirming the Spanish claimant, and renouncing the prospect of the French claimant. Charles of France made a comparable statement: "It has been agreed... to establish an Equilibrium, and political Boundarys between the Kingdoms, whereof the Interests have been, and are still the sad occasion of a bloody Dispute; and to hold it for a fundamental Maxim, in order to preserve this Peace, that Provision ought to be made, that the Forces of these Kingdoms may not become formidable, nor be able to cause any Jealousy; which it has been thought, cannot be settled more solidly than by hindering them from extending themselves, and by keeping a certain Proportion; to the end that the weaker being united together may defend themselves against the more powerful, and support themselves respectively against their Equals." Id. at 195-96. (The entire text of the Peace of Utrecht appears at 177-239.)

58. Id. at $187-88$. 
increase its relative position in the system will set in motion a complex of forces that could eventuate in a defensive alliance and warfare.

The juridical consequences of the Westphalia-Utrecht line of development are carefully and conveniently explicated by Vattel in his Law of Nations, initially published in 1758 . Unlike Grotius, who combines nostalgia for the earlier medieval approach with aspirations for a future order based on higher morality, Vattel does not challenge the prevailing consensus. His work reflects rather than reforms or challenges. As such, it is generally acceptable to decisionmakers at all levels of the political order and, as might be expected, is more influential than other intellectually superior juridical statements. ${ }^{50}$

In my view, Vattel's stature was a direct consequence of his capacity to codify the status paradigm in clear prose. He was praised for his "common sense" and "realism," 60 but such praise only meant that he was a faithful repository of conventional wisdom. With the erosion of the Westphalia paradigm in the 20th century, especially in the period since 1914, there has been a gradual disappearance of the Vattelian consensus on the contents of "common sense," as well as a neo-Grotian movement of sorts. Hedley Bull describes "the Grotian conception," a conception he incidentally deplores, as "a certain conception of international society, whose imprint may be traced in the Covenant of the League of Nations, the Paris Pact, the United Nations Charter, and the Charter of the International Military Tribunal at Nuremberg." 11 These agreements which prefigure neo-Grotian thought call to mind Grotius's own effort to substitute a community of nations resting on natural law norms for the collapsing Christian community

59. A. Nussbaum, supra note 13, at 160 , notes, "Among the legal learned Vattel has never met with much praise." Jeremy Bentham's famous summary of Vattelian reasoning is somewhat, but not entirely unfair: "It is not just to do what is unjust." Nevertheless. Vattel's influence was without serious peer. Edwin Dickinson's study of the relative influence of continental international lawyers during the period from 1789 to 1820 is revealing:

\section{Grotius}

Pufendorf

Bynkershoek

Vattel

\section{Citations in
Pleadings}

16

9

25

92

\section{Court Citations}

11

4

16

38

\section{Court Quotations}

2

8

2

22

Changing Concepts and the Doctrine of Incorporation, 26 AM. J. INT'L L. 239, 259 n.132 (1932), cited and commented on by A. NussBuum, supra, at 162. See also the fuller depiction of Grotian ideas in Lauterpacht, The Grotian Tradition in International Law, [1946] BRIT. Y.B. INT'L L. I.

60. See A. Nussbaum, supra note 13, at 161-63.

61. Bull, supra note 17 , at 50. Professor Bull refers to H. Lauterpacht, INIERNationaL Law and Human Rights (1950) and to C. Jenks, The Common Law of Mankind (1958) as further evidence of the revival of Grotian thinking. 
which had rested uneasily on ecclesiastic authority and religious tradition.

In my terminology, Grotius endeavored to recreate a plausible ideology of central guidance in a situation of increasing disintegration. As long as the historical drift was against him, that is, in the period between Utrecht and World War I, the more statist jurisprudence of Vattel carried the day because it seemed to correspond more closely with configurations of belief, power, and behavior. As 20th century students of the statist paradigm began to uncover anomalies, principally in the form of mutually destructive warfare and of multidimensional interdependence, a swing back toward Grotian conceptions could be discerned both in the work of "far-seeing guides" 02 and even in the characteristic juridical reforms of the time. ${ }^{63}$ Instead of a normative hope, central guidance of a secular sort became a public demand as well as an objective sought after by practical men of affairs. ${ }^{64}$

The time horizons of such a quest encourage misinterpretations, especially by those with little feeling for the rhythm of major historical transformations. There is a tendency either to expect the process to crystallize almost immediately in a world government or conversely to dismiss as irrelevant these early gropings toward central guidance because they have no prospect of taking definitive shape in the near future. ${ }^{65}$ Confusion is also generated by contradictions among concurrent trends, and unless attempts are made to interpret the overall process, there is a tendency to believe that everything is cancelled out. For instance, for every move toward central guidance it is possible to point to a neutralizing move toward sovereign prerogative, whether it be the proliferation of the state system in this post-colonial period or

62. E.g., W. Friedmann, The Changing Structure of International Law (1964); C. JENKS, supra note 61; H. LAUTERPAChT, supra note 61; H. LAUTERPAChT, ThE Function of LAW in the INTERnational Community (1933).

63. These include the constitutional documents of international organizations, especially the Covenant of the League of Nations and the Charter of the United Nations, the Nuremberg Judgment and the later formulation of its conclusions in a document called the Nuremberg Principles, and the main developments in the international law of human rights. For the texts of the United Nations Charter and principal human rights developments, see Basic Documents In INTERnational Law 1-31, 144-232 (I. Brownlic ed. 2d rev. ed. 1972). For a convenient text of the Nuremberg-Judgment and Principles, see Crimes of WAR 88-108 (R. Falk, G. Kolko \& R. Lifton eds. 1971).

64. The enthusiasm for central guidance in the period after World War $I$, and subsequent disillusionment, is well-documented in W. FrIEDMANN, supra note 62, at 275-76.

65. Professor Friedmann provides a characteristic, if restrained, dismissal of central guidance when he concludes that its proponents "ignore the basic social factors of international society." Id. at 276. In the slightly altered context of the basis for a universal system of international law, see the critique of this "make-believe" or "spurious universalism" in McDougal \& Lasswell, The Identification and Appraisal of Diverse Systems of Public Order, 53 AMr. J. INr'L L. 1 (1959), reprinted in M. McDougal \& Associates, Studies in World Public Order 3 (1960). 
the upsurge of statist approaches to the control of the oceans, ${ }^{86}$ until recently the virtual commons of mankind.

My plea is that we take an historical perspective which can accept the fact that a process of paradigm shift may take place over a period of centuries, and that we grow sensitive to the pull and push of forces in the international legal system without losing sight of the cumulative drift toward central guidance. What is "realistic" has happily become a matter of controversy, and objective conditions have changed in ways that alter the notion of "equilibrium," the status of war, the prospects for peace and tranquility, and the role and capacities of territorial actors. Today, as in the 17th century, the time is ripe for preliminary efforts to give juridical shape to a new paradigm of global relations, one that corresponds more closely than statist thinking to the needs, trends, and values of the present state of global politics. The seeds of the new paradigm were planted long ago, most emphatically by the experiences of widespread disillusionment with the balance of power, but only recently has it become plausible to conceive of their presence as the basis for a new paradigm. It is this possibility that will be the subject of the discussion below.

In a sense my analysis reduces to a plea directed at the international legal profession. It is a normative plea that challenges the implicit conservatism of statism and mocks the pseudo-realism of those who, in a period of transition, make the pursuit of stability their primary goal. It is a plea for international lawyers to stop acting as if their most important task were to clarify the rights and duties of the various passengers on the planetary cruiseship Titanic. It is basically a plea to join forces with an infant movement for global reform, but without any illusion that a "quick fix" can be achieved. Indeed, it is a plea to pursue a set of goals that seems hopeless if we consider the array of forces on the other side. It is a plea to make the right choice regardless of the odds, and just because one cares about the future of the human species and the planet earth.

66. I refer here to the extension of state sovereignty over ocean activity formerly regarded as part of the high seas and thus, by legal right, open to all on an equal basis. Given the need to replace the historic regime of "freedom," it could have been possible to allocate regulatory authority to the world community or regional subcommunities rather than to allocate the bulk of authority over the most valuable activities among coastal states. The efforts under United Nations auspices to evolve a new law of the seas started with an idealistic vision of the oceans as "the common heritage of mankind" and ended with an extension of sovereignty achieved mainly at the expense of an earlier domain of community prerogatives. See THE LAW OF THE SEA (Proc. of Ann. Confs. of the Law of the Sea Institute, L. Alexander ed. 1966-1973). 
How, then, can we encourage the development of an appropriate paradigm for international legal studies? Given my analysis, a paradigm will not be appropriate unless it is responsive to the design requirements for guided transition. Such requirements include, above all else, efforts to depict the general direction of the transitional shift already underway, the array of plausible options, criteria for choice among the options, and an action plan by which to maximize the possibilities through which the preferred option could become the probable option. On this basis a new paradigm might be part of a wider effort to resist transition pressures likely to produce a world order solution that is undesirable in terms of either the well-being and development of the human species, or the ecological stability of the planet. ${ }^{67} \mathrm{My}$ ideas are based upon the new juridical paradigm that has been evolving under the auspices of Professors Myres McDougal and Harold Lasswell and their numerous co-workers. ${ }^{68}$ What $I$ believe is needed is to refocus the McDougal enterprise on the specific challenges posed by a transitional context.

Barrington Moore, Jr., has urged reform-minded individuals to compare the costs and risks of reform with those of passivity and reconciliation. Moore realizes that such a comparison "can never be more than a rough approximation." ${ }^{09}$ But only with it, he says, "can we avoid succumbing to the defeatist illusion of impotence within a permanent present or the opposite one of romantic utopianism."70 Moore regards these two illusions as themselves "sources of human misery" and argues that "the effort to overcome them ... is indeed the central justification for the role of the detached observer of human affairs."71 What Moore emphasizes is similar to what Vinogradoff had in mind when he referred to the role of "far-seeing guides" in reshaping the character of international legal studies. It is what I should emphasize as critical at the present juncture if we are to grapple in earnest with

67. The ethical foundations of such a new paradigm are beginning to be developed. See G. Hardin, Exploring New Ethics for Survival: The Voyage of the Spaceship BeAgle (1972); V. Potter, Bioethics: Bridge to the Future (1971).

68. For representative formulations of Professor MicDougal's approach, see M. McDougal \& F. Feliciano, Law and Minimum World Public Order (1961); Suzuki, The New Haven School of International Law: An Invitation to A Policy-Oriented Jurisprudence, 1 YALE STUd. IN WorLd PUB. ORD. 1 (1974); McDougal, Jurisprudence for a Free Society, 1 GA. L. REv. 1 (1966). For assessment and analysis by a sympathetic scholar, see J. Moore, LAw AND THE INDO-ChINa WaR 47-76 (1972).

69. B. Moore, Jr., Reflections on the Causes of Human Misery and Upon Certain Proposals to Elminate TheM 13 (1972).

70. Id.

71. Id. 
the twin dangers of cynical realism, which overadjusts to the inadequacies of the existing order, and utopian idealism, which is so unmindful of existing constraints on reform that it can be of no practical relevance. Both are static postures that fail to comprehend an historically constrained transition process that seems to throw light upon the most relevant range of options.

It is the notion of historical constraint that brings into focus my analysis of the present world order situation. Such a notion does make certain assumptions: for instance, it excludes the occurrence of manmade or natural catastrophe; it excludes an invasion from outer space; it excludes discoveries that enable the whole world population to enjoy affluence and abundance despite the persistence of wide disparities. In other words, I accept a developmental view of the transition process that is neither beset nor alleviated by a deus ex machina. At the same time I do not feel that human capacities for response must be confined to marginal adjustment. Changes in possibilities need to be understood as mutations rather than increments. The whole image of paradigm change implies an abrupt discontinuity; the work of Jean Gebser in studying the evolution of human consciousness is highly relevant because he so clearly associates modes of thought with particular conceptions of space prevalent at a given time. Gebser shows that to deal with the pressures of the contemporary world a holistic way of thinking needs to be developed, and argues convincingly that such a mode is already immanent in consciousness. It is a matter of actualizing, rather than inventing it. ${ }^{72}$ The first phase in an explicit Transition ${ }^{73}$ strategy is to reshape consciousness in a holistic direction that derives inspiration from an ethical position of human solidarity in a context of material scarcity. ${ }^{74} \mathrm{My}$ presentation of the crisis in world order is summarized in Diagram I.

Before we can deal directly with paradigm redesign, some fundamental questions of basic approach need to be discussed. It is important to draw the distinction between adopting a new orientation toward global reform (what I am calling paradigm redesign) and the process of actual reform. The design of the new paradigm is possible immediately and it is also a step in the direction of reform, but the dynamics of reform will be the work of the next several generations.

72. See Gebser, supra note 20; Gebser, The Integral Consciousness, 30 MaIn CuRrents 107-08 (1973). Professor Gebser's principal work, URSPRUNG und GEGENWART (2 vols. 1966), remains untranslated.

73. In the diagram, " $t$ " (transition) is the historical process of drift from the state system in the direction of some new globalist system of world order, whereas " $T$ " (Transition) is the study of explicit ideas about facilitating the realization of a given program for global reform. 
A New Paradigm for International Legal Studies

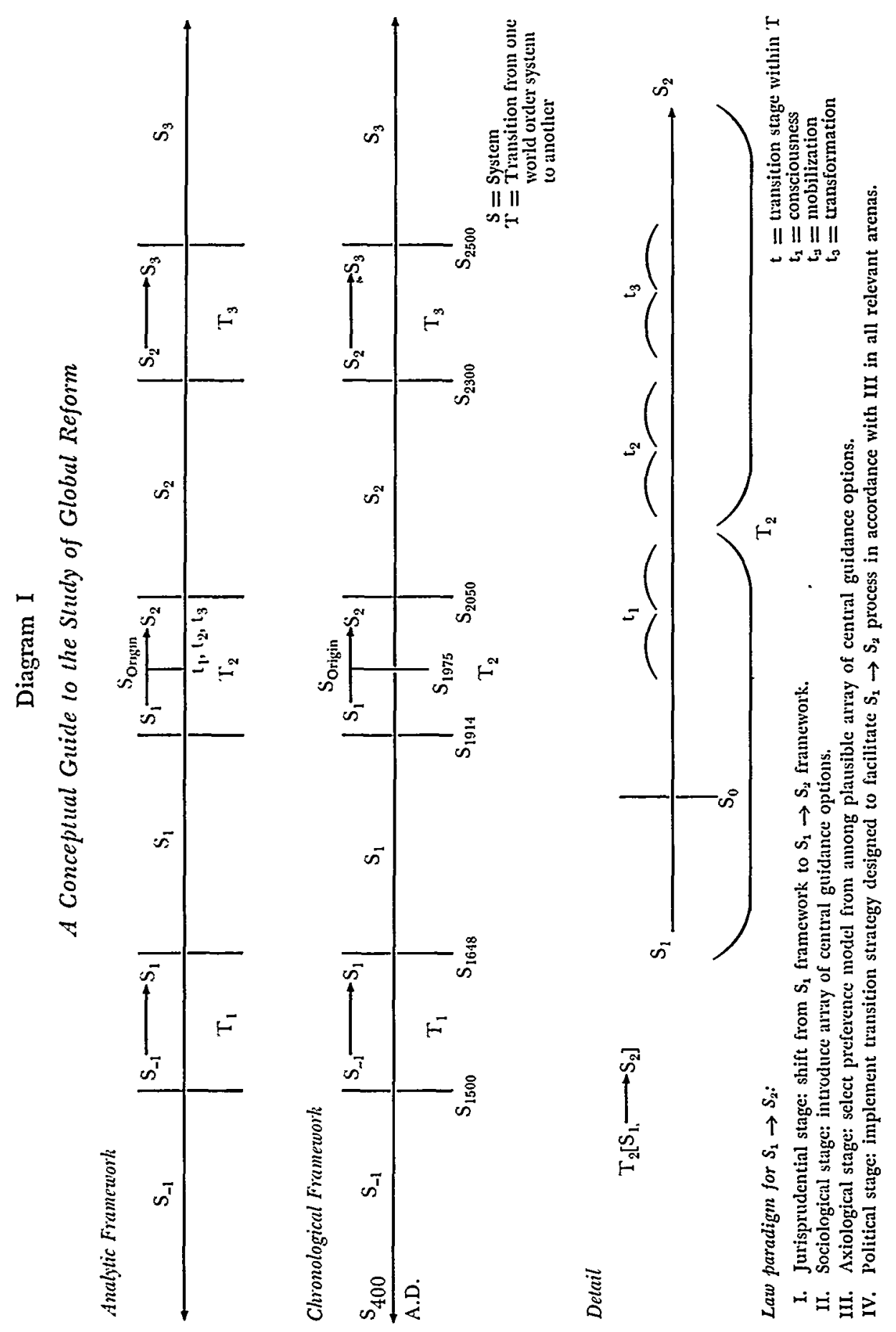


First, there is the age-old issue of freedom and constraint. I am arguing that the flow of historical forces restricts the plausible array of world order options in rather specific ways. The limits of plausibility are set by the requirements for effective mechanisms of nonterritorial central guidance. The possibilities for creative human intervention depend on a prior understanding of the historical context. I am taking a position that denies both historical closure and indefinite openness.

Second, there is the ongoing debate between the tough-minded and tender-hearted over who occupies the high ground of "reality." The literature of international law and relations poses a false dichotomy between Machiavellian geopolitics (the realm of Henry Kissinger) and the globaloney of schemes for instant world government. As I have argued, the balance of power approach to world order is increasingly incapable of satisfying the needs of principal governments or their most powerful constituencies, whereas a utopian fantasy of world government is unconnected with any plausible transition scenario. ${ }^{74}$ It is true, as a recent letter to the New York Times declares, that "no utopian thinking disregarding the realities of the world scene can move us an inch beyond the balance of power. It can only aggravate the calamities of an imperfect world."75 So conceived, the only rational course of behavior is to learn the ropes on the Kissingerian ship of state; any more drastic strategy is repudiated as "utopian." This falsely-posited dichotomy provides the prevailing paradigm with a means to discipline deviants, or at least, to label them as harmless oddities. ${ }^{76}$ In a sense, advocates of instant world government reinforce the statist paradigm by discrediting any movement for drastic reform. I think legalists and other utopians encourage a re-embrace of the status quo; people commonly react that if fantasy is the alternative to reality, then let's give the devil his due and work with reality.

But apologists for each of these positions are placing their bets on horses that have already lost the race. Both Machiavellian geopolitics and utopian legalism are nonviable world order options because they

74. R. Falk, This Endangered Planet: Prospects and Proposals for Human Survival 215-45 (1971), develops such a position. See also R. FALK, supra note 6, at 277.439.

75. Borsody, Letter to the Editor, N.Y. Times, July 28, 1973, at 22, col. 5; for a full and eloquent defense of balance of power thinking, as adapted to an ideological interpretation of global conflict, see E. ROSTOW, PEACE IN THE BALANCE (1972). Even idealistic thinkers lend their authority to the attitudes Borsody expressed. See, e.g., W. FriEdManN, INTRODUcrion to WORLD Politics (5th ed. 1965).

76. For perceptive critiques of reformist thinking from the perspective of the statist paradigm, see F. Hinsley, Power and the Pursuit of Peace (1963); W. Schiffer, The Legal Community of Mankind (1954). For advocacy of world government as the sole alternative to the anarchy and warfare of the state system, see A. Holcombe, A STRATEGX of Peace in a Changing World (1967); E. Reves, The anatomy of Peace (1946). 
fail to perceive the dominant integrationist thrust of contemporary issues. At the same time both positions can be usefully associated with an apt appreciation of prospects for global reform. The intelligent.appreciation of the dynamics of geopolitics does moderate the potential for conflict during a period of consciousness-raising that is just now seriously getting underway. We need an interim period of Kissingerian geopolitics as a "minor premise," to avoid a breakdown of the state system prior to the formation of a widely shared understanding of the prospects for nonterritorial central guidance and of the array of plausible options. Furthermore, we require utopian models of global reform to structure our awareness, provided we appreciate both their failure to provide a transition strategy and their metaphorical provincialism. ${ }^{77}$

There is another spurious issue that must be considered. This is the frequent claim that only a catastrophe could bring about a transformation of the world order system..$^{78}$ Here, the argument concedes that central guidance is likely to come, but not until after another world war. Indeed, among self-styled realists we can identify an optimist as one who believes that the war system can be eliminated from human experience by world order reforms put into practice after World War III; a pessimist believes we may have to wait until after World War IV, or longer. But perhaps we are interpreting the global setting without taking a close enough look at some of its distinctive features. It is, of course, significantly chastening to notice that the main world order adjustments have in the past taken place after wars, as adjuncts to major peace settlements. But is this sequence of response inevitable? Are there reasons to suppose that pre-catastrophe prospects for world order mutations are improving?

I believe that various pressures in addition to the menace of general warfare are now propelling the human species toward a new threshold of choice with respect to fundamental issues of social organization for security and well-being. Many major governments in our age believe

77. For example, the Clark-Sohn model must be understood as an American fantasy that should be perceived as, at most, a particular cultural hypothesis about global reform that must be related to parallel fantasies drawn from the utopias depicted in other world cultures. G. Clark \& L. Sohn, World Peace Through World law (3d cd. 1966). See AwARE OF Utopia (D. Platch ed. 1971); The QUeST For Utopia (C. Negley \& J. Patrick eds. 1952); UtopIA (G. Kateb ed. 1971). It is notable that even Aristotle in The Politics proposed the study of ideal states as well as real ones. THE Politics 80-107 (B. Jowett transl. 1943).

78. For a scenario based on post-catastrophe global reform, see Bundy, After the Deluge, the Covenant, SATurday Rev./World, Aug. 24, 1974, at 14. A. Webre \& 1. Liss, THE AGE of CATACLYSM 153.97 (1974), examine the general case for imminent catastrophe as politically regenerative, but base the prospect for a new world order system on their anticipation of natural (rather than man-made) catastrophe. 
that general warfare would be both mutually destructive and politically inconclusive, i.e., that the damage would be awesome and there would be no winner who could dictate the terms of peace and reconstruction. Indeed, the main military conflicts since Hiroshima, those fought on center stage in the geopolitical arena, have all ended as stalemates. ${ }^{79}$

The future synapses of transition are not so likely to be post-war rehabilitation, but rather the emergent necessity of governments to strike world order bargains concerning subject matter that is global in scope and nonterritorial in essential character. The prime world order imperative is no longer prudential or redemptive, in the historical sense of liberating world society from what the Preamble of the United Nations Charter calls "the scourge of war." Rather, it is ecological, in the broadest sense of interdependence amid scarcity. An overwhelming list of issues makes this perspective inevitable and inescapable: the drive to evolve a world energy and monetary framework and to negotiate a new ocean regime; the challenge of space age technologies relating to such crucial matters as the transmission of information, modification of climate and weather, and the identification of earth resources; the prevalence and potency of private armies; the transnationalization of terrorism; the deteriorating world food situation; the mobility of ideas, people, things; and the universality of holistic imagery of the earth-the Apollo vision of the planet in space on which state boundaries are no more natural than the mapmakers' lines of latitude and longitude.

The issue of timing is fundamental and bewildering. I believe that a paradigm shift is both necessary and possible in the years ahead, and that such a shift would help to influence the transition process in the direction of preferred world order options. Nevertheless, the duration of the transition process cannot be anticipated with any confidence. It might be as short as a few decades or as long as several centuries.

In sum, I see a buildup of largely peacetime pressures to adopt a central guidance option. It is true that the war system remains implicit in the restructuring process and will doubtless play a role that is likely to distort priorities during the transition period. However, the war system's role is one of influencing the shape of the central guidance option, rather than determining whether or not the transition will ever be made. As matters now stand, the prospects are for what I would

79. The 1948, 1956, 1967 and 1973 "wars" in the Middle East can be regarded as phases in a continuous war to resolve the status and domain of Israel; the Indo-Pakistan War of 1971 seems like an exception to the proposition in the text because it ended in an all-out Indian victory. But it was not a major war in a geopolitical sense because the nuclear superpowers were not arrayed in a serious way on opposing sides. Moreover, the main stake of the conflict was to encourage a secessionist effort within Pakistan. 
regard as a regressive form of central guidance, i.e., a reorganization of political relations based on the ability of the few to dominate and manipulate the many who exist in conditions of outrageous and unnecessary misery. Can we change this prospect? Can international law help to alter the present relation of forces now arrayed in support of regressive transition strategies?

\section{III}

At this point I want to clarify what I mean by world order options during this period of transition, by considering the prospect of system change from four perspectives, each of which in my opinion is alert to the possibility in the decades ahead. The perspectives are utopian legalism, the new geopolitics of great powership, the new geoeconomics of the multinational corporate elite, and a global populism based on human solidarity. I believe the utopian legalist perspective need concern us the least, because it lacks both a credible transition scenario and structural leverage. The next two perspectives are far more relevant to the process and prospects of system change. They serve as examples of the kind of reformist initiatives that are potent, because they possess structural leverage, but regressive because they seek to exert it on behalf of values and interests generally incompatible with those I favor. The fourth perspective explicitly adopts values that focus on justice and human dignity, and strives to shape the emerging order of nonterritorial central guidance so that it serves these values.

Four types of world order options thus deserve serious consideration. My interest is to provide a rationale for selecting a preference model which can orient international legal studies within the new paradigmatic framework of a system shift from territorial centralization. For convenience, each type of world order option will be represented by an illustrative case. However, it should be understood that each type of option is itself capable of wide variation with respect to both structure of implementation and normative orientation. Nevertheless, the following four types of options can be usefully stressed at this stage of inquiry:

\footnotetext{
Option A: World Government (illustrated by the Clark-Sohn plan)

Option B: Concert of Great Powers (illustrated by the Kissinger or Pentagonal design)

Option C: Concert of Multinational Corporate Elites (illustrated by the Trilateral Commission)

Option D: Global Populism (illustrated by the World Order Models Project)
} 
These four options will be appraised as world order constructs from three perspectives: (l) considerations of attainability-whether it is plausible, even if unlikely, to achieve sufficient structural leverage under specified conditions to bring the proposed reforms into being; (2) considerations of desirability-whether the proposed reforms would be likely to operate in a desirable manner as assessed by value priorities; and (3) considerations of durability-whether realization of the reforms would produce a reasonably stable international environment in which there would be no strong likelihood of early relapse. Diagram II may aid the reader in the following discussion of these options.

\section{A}

The Clark-Sohn proposals are designed to produce a peaceful and more just world by combining total disarmament with a greatly augmented United Nations. ${ }^{80}$ They provide a model of an alternative world system that seeks to realize values of peacefulness and equity. It seeks as well a balance between the amount of central guidance needed to create confidence in the disarmament process and the amount of protection needed to bar encroachment by the center on zones of autonomy of national societies. As such, Clark and Sohn have evolved a plausible, carefully conceived, enlightened world order system that is probably best classified as a model of weak or limited world government. In effect, the Clark-Sohn plan expects national governments to implement the scheme voluntarily by entering into a new social contract. The fundamental goal is war prevention; the basic nexus of transformation is a constitutional convention.

Such proposals, as matters now stand, are both unrealistic, since they shed no light on the transition problem, and misleading, since they assume that existing elites will either voluntarily evolve a new world order system that diminishes their relative power, wealth, and prestige or will be receptive to such adjustments. To show the promised land across an unbridgeable river is to encourage either quietistic despair (because the future is unattainable) or confirm the status quo (because the present setting is the only meaningful one). Either attitude helps power-wielders discourage recourse to genuine strategies of transformation. ${ }^{81}$

80. See G. CLARK \& L. SoHN, supra note 77 ; for a recent perspective on proposals by Louis B. Sohn, see Introduction to World Peace Throvgh World Law (G. Clark \&. L. Sohn eds. 1973).

81. For an overall critique of legalist thinking about drastic global reform of which the Clark-Sohn proposals are an example, see W. SCHIFFer, supra note 76; W. SCHIFFER, A Critical ANalysis of the Modern Concert of World Organization (1954). For specific critical comments on the Clark-Sohn proposals along these lines, see M. McDoucal \& F. Feliciano, supra note 68 , at $369-70,374$. 
A New Paradigm for International Legal Studies

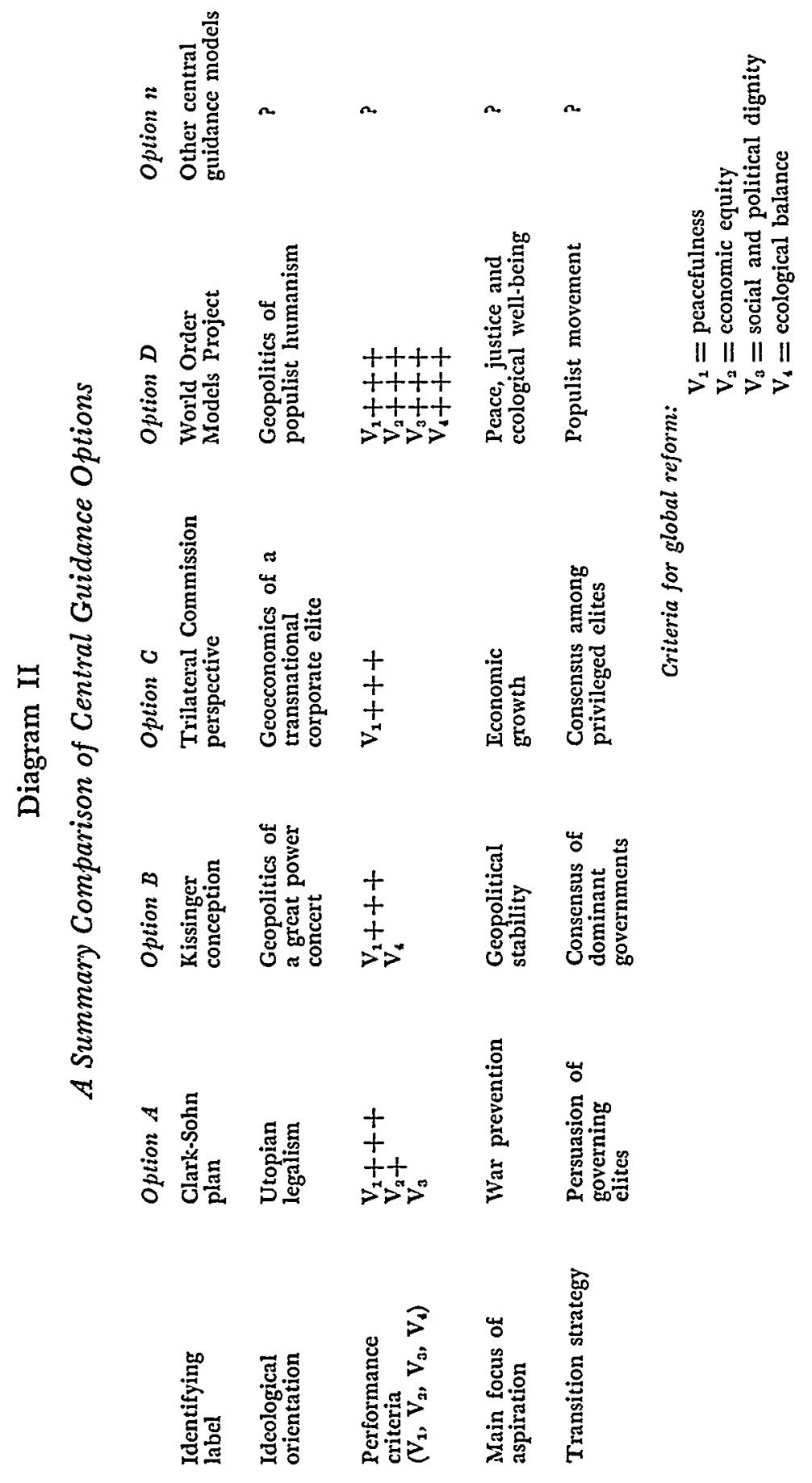


These proposals are a reasonable solution to current challenges, although not the only statement, or even the best statement, of what the goals of global reform should be. But they drop as dead weights on present social reality. ${ }^{82}$ The only "quick fix," one which their proponents usually avoid, would be to tie their advocacy into apocalyptic scenarios of the future; perhaps these proposals are useful instruments to have in the intellectual survival kit should World War III or some other global catastrophe occur which suddenly creates receptivity to change.

To be worthy of investigation, a world order option must have a transition strategy that is credible, as well as a reasonably coherent model for dealing with the challenge of interdependence amid scarcity. It is not necessary, and probably would be misleading, to offer a blueprint for a future world order system at this stage of the transition process; what I call "the fallacy of premature specificity" is characteristic of Option A initiatives, which tend to be static and apolitical.

\section{B}

The Kissinger design seeks to freeze the geopolitical status quo through the moderation of political conflict among the most powerful governments. ${ }^{83}$ If such moderation is successful, then the prospects of managing Third World discontent can be undertaken without much threat to the global status quo. The design is hierarchical and exploitative; it fails to treat economic misery, ecological decay, political repression, or population pressure as genuine world order issues. ${ }^{84}$ In contrast, energy flows, monetary stability, the repression of terrorism, the elimination of drug flows, and the exploitation of ocean resources are high on such a world order agenda. As a consequence, we have a

82. Legalists tend to overestimate reason and rationality in human affairs, as well as the potency of men of good will. As a result, they maintain a naive conception of power that fails to cope with the problem of evil, with irrationality, passion, and vested beliefs. In this regard, the Clark-Sohn proposals, as expectations rather than as statements of preference, seem almost totally apolitical, or what is worse, cven antipolitical. Such a posture on politics for putative reformers constitutes a serious flaw. Nietzsche has delivered the message against the voice of reason in its clearest form; among modern writers who stress the ascendancy of evil in social and political realms are Thomas Mann, Harold Pinter, and William Irwin Thompson.

83. I have argued to this effect in an essay, What's Wrong with Henry Kissinger's Foreign Policy? (Princeton Univ. Center of Int'l Studies, Policy Memorandum No. 39, 1974).

84. This allegation is not refuted by references to Kissinger speeches in which a sensitivity to these issues has been expressed. Rhetorical postures do not entail behavioral positions, but may operate as substitutes for them. I believe the Kissinger conception of world order, to the extent embodied in policy, has not been responsive to the issues mentioned in the text. 
"law and order" variant of central guidance, whose success is fully compatible with domestic repression and global inequality. Kissinger does not appear to lose sleep over military repression or even torture instituted by friendly regimes in South Korea, Brazil, or now Chile; nor does he even appear to exhibit more than a rhetorical concern about Soviet repression of dissent. ${ }^{85}$

The ethos is neo-Darwinian: in a setting of global scarcity all will suffer unless some prevail. Therefore, the powerful will prevail. In a Darwinian sense their prevalence is adaptive for the species, and is also ethically acceptable because those who tend to shape the future are the most deserving. It seems to me that international law, as one would expect, has generally followed the directions set for it by geopolitical tendencies, and that the Kissinger conception of the future is generally, if tacitly, supported by most international lawyers, although without the negative interpretation $I$ have made. ${ }^{86}$

Why is this support ill-conceived? Such central guidance makes vicious struggle in the future far too likely. The dominant actors will be challenged by immensely powerful social and political forces that are prepared to suffer greatly in order to cast off the yoke of hegemony. With expected technological developments it is quite conceivable that a Third World Hitler will emerge and initiate a desperate crusade that could well include recourse to nuclear blackmail. To forestall such danger, the case for surveillance and repression will seem irresistible. We will live in an Orwellian mind camp, made secure by the ultra-sophisticated technologies of human control.

There is a second problem. Ecological planning for the planet seems to require longer time horizons and much better planning and coordination than this Pentagonal design provides with respect to the global process of economic development. With inequality structured into the world order system in a setting of rapidly expanding population, especially among the poorest peoples of the world, it will be virtually impossible to put an effective brake on resource use or environmental deterioration. With self-interest as the main engine of economic distribution, we anticipate no capacity to identify, let alone implement, a concept of planetary interest. Already evident is the decline of what small altruistic element earlier manifested itself in the foreign aid area.

Thus the Kissinger design is self-destructive, violence-prone, and

85. Specific reinforcement of this charge is made in a careful recent assessment of this aspect of Kissinger's foreign policy. Binder, The Pragmatism of Nixon's Foreign Policy, N.Y. Times, Jan. 15, 1974, at 6, col. 3.

86. See, e.g., E. RosTow, supra note 75. 
ecologically hazardous. It purchases a few extra years of material prosperity and geopolitical dominance at immense costs in moral and ecological terms, while incurring grave risks of geopolitical disintegration and ecological collapse.

\section{G}

Option C can be illustrated by the recent dream-child of David Rockefeller, the Trilateral Commission. This Commission intends "to bring the best brains in the world together to bear on the problems of the future." $\mathrm{s}$ The Commission is almost exclusively drawn from the ultra-elite ranks of North America, Japan, and Western Europe, and unless "the best brains" are defined as those inhabiting the most affluent bodies, it has many intelligent individuals, but virtually none of the best brains among its membership. It does bring together a very impressive array of influentials, almost all of whom possess easy and effective access to the topmost levels of power, wealth, and prestige. ${ }^{88}$

In Trialogue, the newsletter of the Commission, Rockefeller is reported as believing that "private citizens are often able to act with greater flexibility than governments in the search for new and better forms of international cooperation." 89 What is not explicit, but may underlie Option $\mathrm{C}$, is a fear about the consequence of uncooperative governments which become beholden to domestic constituencies whose interests are at variance with those of the multinational corporation, because such constituencies become either nationalistic, or ideological, or humanistic.

Why is such an initiative worthy of note? First of all, its formation expresses a general recognition by the elites in the most powerful states that there is an emergent global crisis of unprecedented proportions that involves, in particular, the capacity of capitalism to adapt to the future; it deserves comparison with more globalist and intellectual undertakings such as those sponsored by the Club of Rome.90 Second, the Commission's formation reflects the view that national governments are not necessarily capable on their own of working out the adaptations that are necessary to sustain the existing elites in power in these

87. D. Rockefeller, quoted in Prospectus of the Trilateral Commission (1973). The Commission is described in the subtitle of the Prospectus as "A Private AmericanEuropean-Japanese Initiative on Matters of Common Concern."

88. The membership of the Commission is listed in the Prospectus, supra note 87.

89. 2 Trialogue 5 (Nov. 1973).

90. See, e.g., D. Meadows, J. Randers \& W. Behrens, The Limits to Growth: A Report for the Club of Rome's Project on the Predicament of Mankind (1972); $M$. mesarovic \& E. Pestel, Mankind At the Turning Point (1974). 
three centers of global wealth. Such a nongovernmental initiative can be currently understood as a complement to the managerial geopolitics of Henry Kissinger which, by its stress on a so-called "structure of peace,"01 conceivably imperils the structure of wealth constituted by the capitalist sector of the highly industrialized portion of the world. The Trilateral Commission can be conceived, I think, as a geoeconomic search for a managerial formula that will keep this concentration of wealth intact, given its nonterritorial character, and in light of the multiple challenges to it from Arab oil interests, the Communist bloc, and various expressions of statism. In a sense, the vistas of the Trilateral Commission can be understood as the ideological perspective representing the transnational outlook of the multinational corporation.

This initiative deserves note, furthermore, because the emphasis on devising transnational solutions and on consensus-building among elites is responsive to the nonterritorial dimensions of the crisis in the state system. The Trilateral Commission is an important initiative because it is constituted in such a way as to possess structural leverage: it has a formidable transition capability. But its reformist goals are not concerned with globalist solutions based on the interplay of peace and justice considerations. The Chinese speak of a world divided into predators and the prey, and in these terms, Option $\mathrm{C}$ represents an initiative of the predators. Put less ideologically, the Trilateral Commission embodies a strategy of transition that does not emphasize empathy and equity, much less equality, and hence has to rely upon patterns of dominance, repression, and violence, administered if possible by territorial governments that provide local police protection.

The actual value orientation of the multinational corporate elite as embodied in the Trilateral Commission is difficult to discern, since the Commission is so recent and its overall perspective is still being shaped. As matters now stand, it seems allied to the Kissinger outlook, but more transnational and less governmental (or static) in perspective orientation. That is, the class affinities are cross-cultural and transnational, and there is less emphasis upon distinctive interests of one particular state in the system or of the well-being of its domestic population. The Trilateral Commission also tentatively takes an implicit stand against socialism as a mode of economic organization and as a strategy for carrying humanistic ethics into the real world. The Kissinger design is agnostic on these questions so long as it can keep its own

91. For perhaps the most authoritative statement of the character of "the structure of peace," the cornerstone of the Kissinger foreign policy, see R. NIXON, ANNUAL REPORT ON Foreign Policy, H.R. Doc. No. 96, 93d Cong., lst Sess. 2-13 (1973). 
national structure securely under a capitalist mode of organization and can profitably penetrate most other economies. Indeed, domestic political constraints on foreign economic policy make the welfare of the national population of constituent states much more central to a great power geopolitical solution than to a transnational geoeconomic solution.

The early work of the Trilateral Commission has consisted mainly of a series of occasional papers, "Triangle Papers," on broad issues of international cooperation such as money and energy. ${ }^{22}$ These analyses of current issues, stressing items on the international economic agenda, have advocated liberal solutions to current problems and have stayed away from the adoption of neo-Darwinian tactics. Thus despite its socio-economic class affinities, the Trilateral Commission seems to represent an enlightened variant of Option C; it may indeed be partly regarded as an effort to persuade its transnational economic constituency to reject harsher, more selfish strategies for the protection of its various interests.

George Ball put the case for this transnational economic approach to world order in a form that corresponds closely to the central theme of this article: "The multinational corporation not only promises the most efficient use of world resources, but as an institution, it poses the greatest challenge to the power of a nation-state since the temporal position of the Roman Church began to decline in the 15th century." 93 Richard Barnet and Ronald Mueller initiate their book-length inquiry with a related and striking assertion: "[T] he men who run the global corporation are the first in history with the organization, technology, money, and ideology to make a credible try at managing the world as an integrated unit." ${ }^{44}$ I do not want to imply that David Rockefeller may be best understood as the new Pope Innocent X, but I do believe that there is a new ideology of geoeconomics that is a secular vision of Unam Sanctam. By this I mean only that the transnational ideology of the multinational corporate elite seeks to subordinate territorial politics to nonterritorial economic goals, just as the Papacy in Unam

92. The first several Triangle Papers have been distributed: M. KAJI, R. Cooper \& C. Segre, Toward a Renovated World Monetary System (No. 1, 1973); F. Duchêne, K. Mushakoji \&: H. Owen, The Crisis of International Cooperation (No. 2, 1973); $R$. Gardner, S. Okita \& B. Udink, A Turning Point in North-South Economic Relations (No. 3, 1974); G. Paliano, P. Trezise \& N. Ushiba, Directions for World Trade in Nineteen-Seventies (No. 4, 1974); J. Campeell, G. de Carmoy \& S. Kondo, Energy: The Imperative for a TRILATERAL APPROACH (No. 5, 1974).

93. Quoted in House Comm. on Foreign Affairs, 93d Conc., 2d Sess., Rep. of Official Visit to Congress by a Delegation of the European Parliament 40 (Comm. Print. 1973).

94. Global Reach: The Power of the Multinational Corporation 1 (1974). 
Sanctam sought to place the spiritual sword of the Church above the secular sword of national kings.

What does this new Unam Sanctam offer? It offers efficiency in resource use, maximum economic development, and an end to international political conflict. IBM proclaims from a Manhattan skyscraper "world peace through world trade." The corporate board rooms of the multinational corporation tend to have maps with no political boundaries. In its outlook, and even in its management, the multinational corporation is becoming cosmopolitan; the ideological fervor of the Cold War has been replaced by ideological indifference. The world order solution promised by "the cosmocorp" has been described as "the businessman's peace." Or, as a recent article put it: "Alexei Kosygin has a friend at Chase Manhattan ... and his name is David Rockefeller." 95

What is wrong? Is it not a viable, indeed the only viable way of promoting transition to a post-statist system of world order? Unfortunately, most of the criticisms directed at the Pentagonal design apply here. Option $\mathrm{C}$ is a creature of economic inequality and needs a political support structure. It is not accidental that International Telephone and Telegraph (ITT) tried to organize illegal interventionary efforts to thwart Allende's ascent to power in Chile, or that multinational corporations find the militarism of regimes in Brazil and even Peru congenial to their interests. Of course clumsy efforts at business-sponsored intervention are deplored-most of all, I suspect, by the Trilateral Commissioners themselves. They can hardly help but realize that such a fiasco is discrediting, just as counterinsurgency enthusiasts must have been appalled by the Bay of Pigs fiasco. Even ITT has acknowledged its gaffe by employing a high former State Department official, Samuel de Palma, as its de facto Secretary of State, although disguised by his job description as advisor to the president for international policy. It's a bit like the CIA cleaning house after the Bay of Pigs: the counter-revolutionary policy is not renounced, but only its pursuit by ineffectual and discredited means.

95. Shapiro, Alexei Kosygin has a Friend at Chase Manhattan..., N.Y. Times, Feb. 24, 1974, $\$ 6$ (Magazine), at 11. It seems useful to add a caveat. Referring to the multinational corporation or the multinational corporate elite is a gross simplification. There are various kinds of multinational corporations, with various interpretations of the world and of their interests, and with varying effects on the societies in which they operate. To illustrate, there is a great difference between the manufacturer of consumer durables (requiring a middle class market) and the builder of economic infrastructure in the form of bridges, dams, roads. Nevertheless, despite these crucial diversities, it remains useful and valid to generalize the outlook and impact of the multinational corporation as a globalizing phenomenon of prime significance. 
To thrive in a Third World setting, the multinational corporation needs a repressive, exploitative governmental structure such as that of Brazil. If this kind of national economic setting does not exist, then the corporation's well-being may require diplomatic protection, whether it be of the crude sort that ITT sought from the CIA, or of the more sophisticated sort that resulted after Allende was in power. In other words, the multinational corporate solution is viable only in conjunction with the support of powerful governments that possess strong military capabilities. Multinational corporations appear to depend on the state system even as they act as agents of its transformation. Furthermore, the Trilateral Commission perspective will be as blind to ecological hazard and human misery as the Kissinger design. Perhaps to a greater degree even than national governments because of its class character, the Trilateral Commission is likely to be oblivious to the need for humanizing policies even if carried out at a national level.

Therefore, I find the outlook of the Trilateral Commission unacceptable, despite its effort to mobilize a transnational nonterritorial consensus on world order issues. It remains hegemonial in the extreme; as a result it cannot cope with either the social question (the alleviation of misery), the political question (the elimination of repression), or the ecological question (the defense of the planet and its resources). It is therefore even unlikely to keep its promise to deal with the military question (the avoidance of large-scale warfare).

What general principles can we derive from these responses to the crisis in the state system? First, it is impossible to contribute to the process of changing consciousness for a new world order without a credible strategy of transition. Second, a credible strategy of transition is not necessarily to be applauded if it seeks to sustain or solidify existing structures of exploitation and dominance; such initiatives are illustrative of the right approach, but not conducive to the right outcome. Given my interpretation, the Clark-Sohn proposals can be ignored, whereas the work of the Trilateral Commission or the Kissinger world order design should be actively opposed.

On this basis, we can now proceed to a more positive statement of the problem of the relevance of international law to system change. I believe that it is important to proceed on a transnational basis, to seek structural relevance for a set of reformist goals that emphasize peace, the elimination of poverty, the promotion of social and political justice, and the achievement of ecological balance (i.e., both conservation of 
resources and enhancement of environmental quality). How can international lawyers and international law contribute to such an enterprise? In my view, international law and lawyers can play a constructive role in three major respects: first, by discerning trends toward a new system of global order implicit in various lawmaking contexts; second, by evaluating these trends from a transnational perspective that is oriented around the four value positions enumerated above; and third, by actually using these insights and evaluations in the lawmaking contexts of world policy, of which by far the most important continues to be that of state practice.

\section{D}

Let me now turn to the most difficult task, that of identifying "dangerous knowledge" in the special sense of providing a problem-solving paradigm that is a genuine alternative to the central guidance options that I have discussed in such disparaging terms. The most formidable purveyors of dangerous knowledge are, of course, Professor McDougal and his numerous colleagues spread around the globe. ${ }^{96}$ His enterprise, to create a world public order based on the values of human dignity, is a radical vision of prime magnitude. It is universal in scope: that is, the conception is nonhierarchical, and does not necessarily depend on the persistence of the state system. It is process-oriented in relation to the future: that is, it suggests we create the future by promoting preferred values in all critical arenas, starting now. It is oriented toward the well-being of the species as a whole, and is thus naturally receptive to both an ecological perspective and a futurist concern with assuring the life-chances of subsequent generations.

Because we are in the historical mainstream, it is as yet unclear whether to regard McDougal (and collaborators) as the immediate precursors of a new world order system, in the way that we view Grotius today, or whether the role is a more antecedent one, comparable to that of say, Vitoria or Suarez. ${ }^{97}$ Such a comparison will be more credible when made from the vantage point of the 21st century. We do not

96. This dangerous knowledge is embodied, of course, in the long list of scholarly publications emanating from the New Haven School. For a useful introductory sampling, see M. McDougal \& Associates, supra note 65; 1 Yale Studies in World Pub. ORd. (1974).

97. The main role of these pre-Grotians was to begin to formulate the basis of a law of nations by distinguishing between $j u s$ naturale and jus gentium, the latter being susceptible to human modification and discernible by custom and consent. For a brief discussion of the contribution of Vitoria and Suarez in relation to the work of Grotius, see P. Corbetr, supra note 13, at 17-24. 
know whether the Law of the Sea Conference ${ }^{98}$ or some world energy conference bound to occur in this decade will be viewed from the perspective of the future as our Westphalia, or whether the efforts to strike world order bargains among governments in the 1970's will be seen instead as antecedent events in the sense that Augsburg was antecedent to Westphalia. ${ }^{99}$ And, of course, we do not yet know whether the McDougal jurisprudence will underlie the paradigm which will eventually prevail in the emergent era of nonterritorial central guidance. Its highly abstract formulations could be stretched to cover the hegemonical options that we discard, but its humanistic animus is both genuine and directly responsive to the objective realities of the misery that afflicts most of the human race.

The McDougal breakthrough in reformulating on a global level the relevance of law to human affairs is surely "dangerous knowledge." It threatens the prevailing paradigm, and hence draws fire from certain kinds of professionals who continue to believe in the Westphalia paradigm. ${ }^{100} \mathrm{McD}$ ougal himself is an almost ideal purveyor of dangerous knowledge, with his uncanny mix of inconsistent qualities which are essential for discharging such a role. First of all, he has the strength and largeness of personality to build a following that is broader than normal partisan lines. Second, the message is helpfully disguised by the medium: the obscurity and abstractness of formulation actually require someone to either learn the new paradigm as a

98. It remains unclear whether the 1974-1975 effort to negotiate a new law of the seas will eventuate in a widely ratified and seriously implemented treaty. It appears likely that no major innovation in supranational authority will eventuate, either with respect to administration, revenue-sharing, environmental protection, or dispute settlement, with the possible exception of the regulation of deep sea mining operations. Hence, the major effect of this attempt at global reform is likely to be an extension of coastal sovereignty over a 200 mile economic zone. Such a development can be regarded as an accentuation of the state system, rather than a step toward its supersession. See note 66 supra.

99. The Peace of Augsburg (1555) foreshadowed the principal terms of the Peace of Westphalia by almost 100 years. At Augsburg each prince was given the right to determine whether Catholicism or Lutheran Protestantism would prevail within his territory; dissenters were assured a right of emigration. In 1648 the idea of religious toleration was broadened at Westphalia to include non-Lutheran Protestant sects and adherents of the Christian faith at variance with that of the prince; both could choose between emigration and toleration.

Perhaps in retrospect the breakup of the oil tanker Torrey Canyon in 1967 will be seen as the comparable originating event in the nuclear age.

100. Because of the decorum of the profession, much of this hostility to professor McDougal's works is expressed indirectly by mocking asides and the like, and is deleted from published texts. One interesting example of criticism that comes from an international lawyer who shares McDougal's conservative views on immediate issues, but senses an underlying cleavage is Freeman, Professor McDougal's "Law and Minimum World Public Order," 58 AM. J. INT'L L. 711 (1964). I have written a response explaining my bases for supporting McDougal on a fundamental level. R. FALK, THE Status of LAw IN INTERNATIONAL SOCIETY 654-59 (1970). 


\section{A New Paradigm for International Legal Studies}

whole or ignore the entire effort. ${ }^{101}$ And, finally, McDougal's politically conservative views on current issues ${ }^{102}$ disguise his real message and permit the subversive reorientation of thinking to gain access to policymaking at high levels without being detected as such. ${ }^{103}$ Thus, the message has to do with a processive, value-oriented approach to norms that are appraised by reference to global criteria. These criteria are directly at variance with the national-interest-oriented, Machiavellian calculus that arises out of the statist paradigm as codified by international lawyers, especially since the mid-18th century, when Vattel's treatise was published.104 Now it is true that McDougal's work is transitional, deriving substance from the state system as well as moving beyond it. McDougal is no utopian. On the contrary, his writing always shows a lively sense of realism, and an understanding of the connection between his appraisals and the dominance of states and their rival aspirations. ${ }^{105}$

To deal with the present global situation from a legal perspective, I believe we need to develop the McDougal paradigm in several directions. ${ }^{108}$ I regard these developments as implicit in the present formulations, but believe that they must be made more explicit. The domain of ambiguity must be restricted as we move deeper into the 1970's, because we are confronted, as I have suggested, by a set of relatively discrete world order options. The issue of choice and recommendation becomes paramount. The advocates of Options $\mathrm{B}$ and $\mathrm{C}$, the geopolitical minimalists and the geoeconomic maximalists, have assured

101. Professor Corbett makes an intriguingly similar comment about Grotius's tendency to confuse the law of nature with the law of nations when he conjectures that it was "conceivably a calculated confusion designed to endow his law of nations with the authority of the law of nature." P. ConBETr, supra note 13, at 23-24.

102. See M. McDougal \& Associates, supra note 65, at 763.843; McDougal, Foreword to J. Moore, LAW AND THE INDO-ChINA WAR at vii-xiv (1972); McDougal, The SovietCuban Quarantine and Self-Defense, 57 AM. J. INT'L L. 597 (1963).

103. See generally R. FALK, supra note 100, at 342-77, 642-59; R. FALK, LeGaL ORdER IN A VIOLENT WORLD 80.96 (1968); Kissinger, The White Revolutionary: Reflections on Bismarck, in Philosophers AND Kincs: Studies in Leadership 317-53 (D. Rustow ed. 1970).

104. All of the principal international law treatises illustrate the predominance of the statist paradigm. See, e.g., C. Hyde, INTERnational Law ChIEFLy AS INTERIRETEd AND Applied BY THE United States (2d rev. ed. 1951); D. O'Connell, InTERnational Law (2 vols. 1965); L. Oppenheim, International Law: A Treatise (H. Lauterpacht ed. 1948).

105. This point is evident in an influential study of the relevance of domestic public order to the prospects for the growth of world law. MicDougal \& Lasswell, supra note 65, at 3 .

106. I appreciate the difficulty of implementing such a recommendation. A radical (in the sense of "root" or "fundamental") redefinition of what constitutes knowledge for lawyers underlies the work of the New Haven school. To extend that redefinition in new social and political directions would require a degree of intellectual flexibility not common among intellectual innovators, who tend, perhaps out of necessity, to be purist rather than eclectic in their evolution. Nevertheless, the argument for innovation is advanced in the text in the hope that at least an altered dialogue arising out of a dynamic challenge and response will result. 
power, wealth, prestige, and access to media. Do advocates of Option $D$ have any offsetting capabilities? I believe they have a superior understanding of the historical situation and an authenticity that is safeguarded by their powerlessness; that their line of recommendation appears to have the best insight into the well-being of the human species and the viability of the planet is also a source of political and moral strength. Option $\mathrm{D}$ proponents are beginning to become participants in the emerging debate on global reform. ${ }^{107}$

As matters now stand, McDougal's approach to global reform does not relate itself specifically to the context of critical choice. Indeed, it even allows advocates of Option A and B to adopt his framework of reasoning and rhetoric, without altering their incompatible behavioral modes. Let me be more specific with reference to several issues:

Values. McDougal's values are not specified in relation to any of the outstanding problems of mankind such as poverty, population pressure, violence, and ecological decay. As a result, elitist perspectives can employ his terminology to disguise their indifference to a public order of human dignity. I think that the values of a new paradigm for international legal studies must be placed in direct relation to the agenda of concrete problems facing the human community.

Governments. McDougal tends to identify the representations of governments with the well-being of the peoples of the world. In my view, such an identification runs contrary to fact with respect to any humanistic schedule of values. In many parts of the world, governments regard most of their own citizens as potential or actual antagonists and rely on repressive means to sustain their own power. Therefore, I believe it is necessary to draw a sharp distinction between the well-being of governments and the well-being of peoples or their countries. ${ }^{108}$ This distinction must be drawn vis-à-vis the values specified in terms of problems (or social goals). ${ }^{109}$

107. These include even such a mainstream analyst of foreign policy as Brzezinski, U.S. Foreign Policy: The Search for Focus, 51 ForeIgN AFrairs 708-27 (1973).

108. A characteristic of statist-paradigm thinking is to grant national governments a monopoly over representational legitimacy, i.e., the competence to represent the wellbeing of the citizenry. But cf. McDougal, Lasswell \& Chen, Nationality and Human Rights: The Protection of the Individual in External Arenas, 83 YALE L.J. 900 (1974). Where national governments sustain power by repressive as distinct from voluntaristic and contractual means, such a presupposition does violence to any ethical assessment of public well-being. Most preferred models of future central guidance (and clearly Option D) distribute representational legitimacy among several categories of actors.

109. This distinction becomes clearer (and easier to make) if one shares William Irwin Thompson's brilliantly expressed skepticism regarding governmental capacities:

Some of our problems stem from the fact that authority today pretty much comes from those who have power. What we need is a clear distinction between authority and power-as in the days of Christ and Caesar before the papacy. We must realize that there are areas of human culture in the imagination, in religious instincts, in 
Central guidance. McDougal is nowhere explicit about the historical pressures toward nonterritorial global integration and the principal ordering options which can be derived therefrom. I believe it is of critical importance for the new paradigm to pose these choices and to endorse the image of central guidance which corresponds most closely with the performance criteria set forth. Of course, it should be understood that just as Westphalia did not identify precisely the time at which the state system originated, so any emergent central guidance system will evolve in new directions, toward new goals, embodying the seeds of one or more new paradigms within itself.

Transition strategy. Because of its noncommital approach to the policy content of world order values and to the shape of the future world order system, McDougal's approach never describes any path of transition from the present late phases of the state system to the emergent form of central guidance most likely to realize preferred values.

The World Order Models Project can be understood as an unwitting attempt to develop the New Haven approach so that it better satisfies the needs for a global reform movement. The World Order Models Project (WOMP) was organized in 1967 by Professor Saul Mendlovitz under the auspices of the Institute for World Order, and consists of eight regional groupings of scholars: Soviet Union, Africa, India, Japan, Latin America, Western Europe, United States, and a selfconsciously nonterritorial transnational perspective. ${ }^{110}$ After meetings among the directors over the past five years, each participating group in WOMP is producing its own book depicting proposals for global reform by the end of the century. ${ }^{111}$ There has been no effort to achieve a consensus, except to agree on a common framework of inquiry. The research directors have agreed to identify the goals of global reform as

the full dimensions of human culture rather than its mere technocratic husk that are important and that have to be affirmed. If we look upon our Presidents as colorless managers and develop alternative systems for cultural regeneration, then I think we have ways of creating new institutions that aren't weighted down with institutional inertia.

Thompson, The Mechanists and the Mystics, I NoOSPHERE 1-2 (1973).

110. See Mendlovitz \& Weiss, Toward Consensus: The World Order Models Project of the Institute for World Order, in INTRODUction to WORLD PEACE THROUGH WORLD LAW, supra note 80, at 74-97.

111. These books will be published individually in 1975 and 1976. Each book is an independent venture. However, early drafts were commented upon at meetings of the research directors held in the 1970-73 period; and a common acceptance of the four world order values underlies the work of WOMP. In actuality the manuscripts exhibit a surprising degree of diversity; they treat the transition concept in quite different ways, ranging from superseding the state system to merely reforming it. The first books in the series are R. Kothart, Footsteps into the Future (1975); A. Mazrui, A World Federation OF Cultures (1975); ON THE Creation of a Just World ORDER (S. Mendlovitz ed. 1975). 
minimization of violence, maximization of social and economic wellbeing, maximization of social and political justice, and maximization of ecological balance. There is also agreement on the need to make proposals that are desirable and attainable, and to indicate the contours, at least, of a world order solution to the problems of the present system. Despite this shared outlook there is considerable diversity as to relative weighting of values, preference models, transition tactics and strategies. ${ }^{112}$

In my own WOMP book $A$ Study of Future Worlds, I set forth a framework (reflected in Diagrams I and II) with respect to the realization of a preferred form of central guidance that is relevant here. The change of world order systems comes about as a consequence of a threestage transition process. ${ }^{113} \mathrm{My}$ argument is that the primary concern of the present stage $\left(t_{1}\right)$ is consciousness-raising, by which I mean the beginnings of a consensus as to world order challenges and an acceptance of a value orientation similar to Option $D$. In my $S_{2}$ world-that is, a system in which the four performance criteria are substantially realized-the patterns of central guidance are organized around four corresponding functional areas. These functional systems are linked with technical organs of coordination and political organs of oversight. The political organs have tripartite representation: peoples, nongovernmental organizations and governments. The constitutional structure sacrifices efficiency to achieve diversity and inhibits abuse of concentrated power. I regard intermediate forms of central guidance as the most plausible, i.e., those which involve a net increase in the capacity for global administration, but not necessarily a net increase in bureaucratic presence vis-à-vis human existence at most levels of social organization. In Option D, I envision two countervailing organizational tendencies: (1) centralization of functional control and planning to enable equitable allocation of scarce resources, and (2) decentralization of political structures combined with localization of identification patterns. On the level of bureaucratic presence and loyalty attachments there is envisioned by the end of $t_{3}$ an outward mutation in the direction of central guidance, and an inward mutation in the direction of localism, subnational autonomy and participatory relevance.

Admittedly, it is difficult to expect very much to emerge from a group that has chosen an acronym as atrocious as WOMP. As a partici-

112. I have depicted the WOMP/USA conception of central guidance more fully in R. FALK, supra note 6, at 224-76. As research director of WOMP/USA my conceptions about global reform represent the basis of this book and are similar in tenor to the outlook of this article.

113. See diagram at p. 995 supra. 
pant in the project I am nevertheless very enthusiastic about our experience to date: for the first time a nonaffiliated group of scholarsmainly nonlawyers-has coordinated on a worldwide basis an inquiry into the prospects for global reform in this century. It is no more than a first step in the consciousness-raising process that must occur, but I believe it is a notable step because it puts a program for global reform into the center of practical politics.

Of course, skeptics will abound. What difference can such an initiative make in a world ruled by petropolitics and missile postures? There is a Zen saying: "If I raise my little finger I alter the course of the stars." The point is not that the pebble causes a ripple, but that we do not have a firm grasp on the causation of social change at the global level. In these circumstances, it at least makes sense to raise one's little finger, especially when adversaries are raising their hands and stamping their feet. It is also only sensible to be tentative about expectations for the future, and to relate to developments as they unfold. The literature of global reform is marred by the prevalence of congealed legalism. This stance is at variance with the dynamic, process-oriented approach that is required by a context of transition.

\section{E}

Although analytic purposes may require us to distinguish as sharply as possible among the principal central guidance options, certain dangers do arise from such artificial separation. The options I have described are ideal types; in actuality we are dealing with human beings, whose interests, values, roles, and consciousness may overlap the boundaries set by the options as depicted. I would expect the overall context to lead adherents of one option to react to and learn from adherents of competing options, whether by reading each other's books or by borrowing each other's rhetoric and perspectives. Indeed, Option $D$, as "the enemy on the left," so to speak, may exert its behavioral impact indirectly, via assimilation by the principal exponents of Options $\mathrm{B}$ and $\mathrm{C}$. To illustrate, it seems clear that the importance of Norman Thomas's Socialist Party should not be gauged by its unimpressive results at the election polls, but by the extent to which its thinking shaped the New Deal programs of the mainstream Democratic Party. Similarly, if a populist movement for global reform of any magnitude gets started in key countries such as Japan, France, Germany, India, the United States, and within the ranks of the Soviet and Chinese Communist parties, then it is likely to reshape the way in 
which governments and multinationals go about fostering their objectives in the transition interval. Thus Options $B$ and $C$ would most likely be skewed in the direction of $D$ even if $D$ itself never achieves independent potency.

The linkages between Options B and $\mathrm{C}$ are also of critical importance in the years ahead. One question is whether the proponents of Option $\mathrm{C}$ will be able to strike a mutually acceptable bargain with the managerial elite of leading socialist societies, thereby establishing an economic ethos that is global and nonideological in character. Another question is whether the interests of Option C can be safeguarded if they run seriously counter to nationalist demands, especially if populist pressures intensify in key countries. In essence, this concern involves the degree to which the multinational elite can pass upon, or at least exercise a veto over, candidates for high governmental office. As the years pass, it will become clearer whether the multinational elites are the servants or the masters of the governmental elites-whether Option $\mathrm{C}$ crowds out $\mathrm{B}$, or vice versa. Put differently, will the multinational elite be able to call upon the governmental system to enforce its economic claims and to discourage or shatter political resistance, or will the governmental system evolve a regulatory approach that superimposes nationalist or populist values upon the profit and productivity ethos of corporate operations?

At present, an alarming symmetry of motives is developing between those who adhere to Options B and C. Most governments and virtually all multinationals are threatened by ambiguity and pluralism; their distinct interests prosper through patterns of firm control. So long as a government welcomes business operations according to the profits and productivity rationale, it matters little whether a political ideology drawn from the left or right prevails. Therefore, it is easy for corporate elites increasingly to perceive themselves as apolitical, as well as anational and amoral. It is not surprising that capitalist tycoons return from China filled with enthusiasm, after having witnessed order and regimentation on a grand scale. For both global businessmen and managers of government bureaucracies, reliability and predictability are the prime requirements for successful operations; dissension, opposition, and ambiguity are characteristics that can wreck things. Therefore, the populist bias of Option $\mathrm{D}$ is antagonistic to the basic drift of Options B and C, at least given the distribution of present value orientations and relation of forces. Such antagonisms could shift to affinities if the political context were to change in relevant ways, for example if a world depression or prolonged ecological challenge were 
to shift the basic political-economic orientation from satisfying the wants of a relative few to meeting the needs of the many. Such a shift is the humanist alternative to a neo-Darwinian response, as we begin to face worldwide shortages of both renewable and nonrenewable resources.

\section{IV}

It follows from what $I$ have said that we need a new paradigm for international legal studies. To convey a sense of its contours I would like to emphasize five elements: (1) a framework of inquiry that is global, explicitly normative, futurist, and systematic; (2) an orientation toward inequity that is shaped by an appreciation of the transitional character of the international system; ${ }^{114}$ (3) a recognition that the outcome of transition will be the emergence of a system of nonterritorial central guidance; (4) an understanding that the actual shape of the emergent nonterritorial central guidance system will be conditioned by the interplay of statist, business, and populist social forces; (5) a consensus that the most beneficial of the plausible central guidance options will reflect the priority of populist claims for peace, economic equity, social and political dignity, and ecological balance.

I believe that a jurist who is alert to these five elements will be able to acquire a far more relevant understanding of specific legal controversies than he could from the perspective of the older statist paradigm. For vocational purposes it remains desirable to equip students to operate within the statist paradigm, which remains dominant in most sectors of power, wealth, and prestige. From an educational perspective, however, what is now needed is an approach to international legal studies that is anchored in the statist paradigm, but with one eye cocked on the emergent central guidance paradigm.

My point becomes clearer if we look at the various tides of fervent advocacy generated by the question "Should the United States ratify the Genocide Convention?" It is possible to oppose Senate ratification of the Convention because it amounts, as some have phrased it, to " $\mathrm{a}$ pious fraud"; the guilty governments are willing to ritualize the condemnation of genocide precisely because they are confident that it will never be enforced against them. At the same time, right-wing agitators are stirred to fury by the prospect of Senate ratification. A group called

114. Hence, in acting to overcome poverty and economic disparities in the world, priority should be given to those approaches that help create procedures, norms, and institutions of the sort that would facilitate the emergence of Option $D$ as a world order solution. In other words, with any concrete issue of world policy, short term tactics should reflect long term preferences for global reform. 
Liberty Lobby warns that the Genocide Convention is being "pushed by aliens to help destroy our American culture and serve the devious ends of hostile forces carefully planted in our midst!"115

On the other side, the main proponents of ratification, including Senator Proxmire and a group of Yale Law School faculty members, argue that " $[\mathrm{r}]$ ejection of the Convention will diminish United States capacity to influence others to comply with human rights laws and is likely to weaken the international protection of human rights." ${ }^{110}$ But is the United States Government really committed to the promotion of human rights? If so, why has it trained and supported some of the most repressive police forces in the world? Why has it not responded to the documented accounts of genocide in Burundi? ${ }^{117}$ Why does it overlook its own direct responsibility for the torture of political opponents even in societies, such as South Vietnam or Uruguay, where there is considerable American leverage over official policy? ${ }^{\text {t1 }}$

Oddly enough, I think all the parties to the dispute over ratification have a pretty strong position. It is true that the claims of the Convention are pious frauds, given the realities of genocide. But it is also true that the claim to hold government officials, including our own, criminally accountable for systematic repression of distinct ethnic groups represents a drastic claim against the state system. This claim is especially drastic given the persistence of widespread hard-core genocidal activity, and the pervasiveness of official patterns and practices, including those by the United States, that strike some foreign and domestic observers as "genocidal."

It is true that failure to ratify would weaken the credibility of United States objections to human rights violations elsewhere in world society. However, it is also true that, given the controversial United States record on human rights issues, ratification would heighten international cynicism about the status of international law. Interpreting this ratification debate in world order terms, we see a tug of war between the opposed paradigms of statism and central guidance, as well as an anticipatory struggle of sorts among some of the central guidance options. For instance, those who accept Option D and are firmly en-

115. Quoted in Large, Senate is Due To Vote On A Treaty Soon-One Submitted in 1949, Wall St. J., Jan. 17, 1974, at 1, col. 3.

116. Letters to the Editor, N.Y. Times, Feb. 7, 19'74, at 36, col. 9.

117. For news accounts, see N.Y. Times, May 21, 1972, at 11, col. I; June 11, 1972, at 1, col. 2; June 17, 1973, at 1, col. 2; see also R. Morris, M. Bowen, G. Freeman \& K. Miller, Passing By: The United States and Genocide in Burundi 1972 (1973).

118. H. Brown \& D. Luce, Hostages of War: Saigon's Politicar. Prisoners (1973); R. Orman, The Ultimate Form of Corruption, in CrIMEs of WAR, supra note 63, at 255-57; An Interview with Philip Agee: Inside the CIA, InTercontinental Press, Feb. 10, 1975, at 173 . 
trenched in the central guidance paradigm would be most likely to find it useful to point an accusing finger at their own government. In that sense they, like the Liberty Lobby, perceive the Genocide Convention as "subversive," but unlike their reactionary colleagues, the world order populists welcome such subversion as beneficial.

My point may be clarified by an example; take the Nuremberg trials. There are those who speak of "the fallacy of Nuremberg," 110 by which they mean that because the Nuremberg decisions are incompatible with statism, they will therefore not be respected. However, these spokesmen overlook the second-order effects of the Nuremberg precedent. These second-order effects involve reinforcing a populist and cosmopolitan conscience in matters of war and peace, a conscience which was made manifest, for instance, in "crimes" of resistance carried on by Americans during the Vietnam War. Daniel Ellsberg is a prime example of a person who was actually influenced by the Nuremberg Obligation to take steps which he perceived at the time to be illegal. In other words, he decided to implement his understanding of the Nuremberg Obligation to act in opposition to crimes of war, even when such action was in violation of domestic law. ${ }^{220}$

Let me generalize this form of analysis of international law issues. If we are concerned with the relevance of the paradigm shift underway, then there is a variety of subject matter ripe for illuminating analysis. For example, we might explore subject matter in which lines of significant interdependence transcend the boundaries of national jurisdiction, such as the regulation of multinational business or of international terrorism; the assessment of liability for environmental damage, either as a result of spatial diffusion or of territorial and oceanic interaction; the regulation of global monetary policy, of commodity pricing policy, or resource conservation policy. International issues which involve dangerous forms of scarcity, including protection of endangered species of the Great Whale, allocation of rights to fish on the high seas, protection of land, sea, and air against environmental decay, and world population policy (is it a matter of Argentinian prerogative to plan a doubling of her population by the year 2000?) are also appropriate focuses.

World food policy also needs to be explored: e.g., is it a matter of

119. The most careful account along these lines is E. Davidson's appropriately titled yolume, The Nuremberg Fallacy: Wars and War Crimes Since World War II (1973). Davidson's book illustrates the dichotomous view that since world governmental ideas do not work we are thrown back on unrestrained statism. See note 76 supra.

120. On this line of reasoning, see Falk, Ecocide, Genocide, and the Nuremberg Tradition of Individual Responsibility, in Philosophy, Morality and International Affairs 123-37 (V. Held, S. Morgenbesser \& T. Nagel eds. 1974). 
sovereign prerogative to leave cropland idle or underdeveloped when aggregate world food shortages are producing large-scale famine? Similarly, we might examine more closely matters in which nonterritorial actors are playing increasingly significant roles-for example, the role of multinational corporations, of specialized international institutions, of world social and political movements, of humanitarian initiatives like Amnesty International or the International Committee of the Red Cross, of movements for global reform like the Trilateral Commission, the Club of Rome, or the World Order Models Project. Finally, we might look at areas where legitimacy and loyalty are shifting away from the nationalist focus characteristic of the state system. ${ }^{121}$

I am arguing that a reverse process is now underway through which loyalty and legitimacy are shifting away from the state in two directions simultaneously: toward the center of the globe and toward the specifics of community and sentiment. Hence, it is important to stress the role of the individual in war/peace and human rights settings, the role of subnational movements for self-determination, and the significance of cosmopolitan identifications with religious and political movements. ${ }^{122}$ At a minimum, international lawyers should study the transition context and appraise it by reference to the criteria associated with a central guidance paradigm. Even more desirable would be an appraisal of legal developments from a WOMP or global populist perspective, an appraisal that would be alert to the desirability of strengthening the prospects for an Option D solution to the world order problems of our era.

\section{Conclusion}

International lawyers, including even those associated with the New Haven approach, have not yet related directly enough to the transitional historical situation that is already underway. We are moving toward a new world order system based upon an augmented capacity for central guidance and an increased role for nonterritorial actors. The value predispositions of these actors are not predetermined. Nevertheless, the evidence seems to support a pessimistic view of the capacity of these actors either to sustain minimum conditions of a tolerable

121. See generally Schaar, supra note 8.

122. It is relevant to note that the Chilean junta under Pinochet has, in addition to moving against its political opponents, sent leaders of Eastern religious sect movementssuch as that of Maharaj Ji-to prison for indefinite periods. A religious movement with ethical goals and a transnational frame of reference deprives the state mechanism of loyalty and undermines its claims of legitimacy. 
world order, or to achieve an arrangement that promotes human development and well-being for all the peoples of the world. The drift is toward some new kind of geopolitical and geoeconomic hegemony sustained by a neo-Darwinian ethos and implemented by persuasion where possible, coercion where necessary, and violence wherever lesser forms of coercion seem insufficient.

I believe that international lawyers can make better use of the fact that choice is still possible in the area of value orientation. They can help create an alternative vision of central guidance that is built around the values of human dignity, and that is oriented toward the possibility of a planetary community joined together by contractual bonds rather than by hegemonical bondage. At this stage in transition, the primary need is to interpret this unprecedented historical opportunity, as well as to expose the multiple jeopardies that also are present and likely to be aggravated if either Option B or C becomes substantially realized over the next several decades without prior shifts in their controlling ethos. International law will be a testing ground for the relative strength of social forces favoring $\mathrm{B}, \mathrm{C}$, and $\mathrm{D}$; it is up to humanistically inclined international lawyers and others to join the issue by mobilizing their resources in favor of Option $\mathbf{D}$.

Can it happen? Can Option $D$ prevail over the forces arrayed against it (or, alternatively, can Option D reshape Options B and C)? Hannah Arendt's view as to whether her version of Option $\mathrm{D}$ can be achieved provides a relevant perspective:

But if you ask me now what prospect it has of being realized, then I must say to you: Very slight, if at all. And yet perhaps, after all, in the wake of the next revolution. ${ }^{123}$

And by revolution, Arendt means not a violent seizure of state power, but an upsurge of energy directed toward reshaping the priorities that now dominate the political process.

123. H. ARENdr, Crises of the Republic 233 (1972). 